\title{
The Shareholder Base and Payout Policy
}

\author{
Andriy Bodnaruk and Per Östberg*
}

\begin{abstract}
We examine the relation between the shareholder base and payout policy. Consistent with the idea that the shareholder base is related to the cost of external financing, we find that firms with small shareholder bases have lower payout levels and maintain higher cash holdings. We show that undertaking an open market repurchase results in a significant reduction in the size of the shareholder base. Consequently, we find that firms with small shareholder bases are less likely to undertake a repurchase (reduce the shareholder base even further) and are more likely to pay special dividends.
\end{abstract}

\section{Introduction}

Finance practitioners acknowledge that having a broad shareholder base is an important factor for many corporate decisions. For example, in a recent study of firm payout policy, Brav, Graham, Harvey, and Michaely ((2005), p. 523) survey financial executives and conclude, "With respect to payout policy, the rules of the game include ... [to] have a broad and diverse investor base." In practice, the acquisition and management of the shareholder base is the task of the investor relations department or an investor relations firm. ${ }^{1}$ Wolfe Axelrod Weinberger Associates LLC, an investor relations firm, states in its company

\footnotetext{
*Bodnaruk, abodnaru@nd.edu, Department of Finance, University of Notre Dame, 238 Mendoza College of Business, Notre Dame, IN 46556; Östberg, per.oestberg@bf.uzh.ch, Department of Banking and Finance, University of Zürich, Plattenstrasse 14, 8032, Zürich, Switzerland. Insightful comments and suggestions were received from an anonymous referee, Liam Brunt (a discussant), Shane Corwin, Magnus Dahlquist, François Degeorge, Mara Faccio (a discussant), Miguel Ferreira (a discussant), Francesco Franzoni, Gustavo Grullon (a discussant), Paul Malatesta (the editor), Kjell Nyborg, Raghu Rau, Peter Schotman, Paul Schultz, Andrei Simonov, Andrew Winton, and seminar participants at the 2009 American Finance Association meetings in San Francisco, the 2008 CEPR Symposium in Financial Markets in Gerzensee, the 2009 European Finance Association meetings in Bergen, the 2008 European Winter Finance Summit, the 2008 State of Indiana Conference, Michigan State University, the University of Lugano, the University of Maastricht, and the Norwegian School of Economics. Financial support from Bankforskningsinstitutet, the Jan Wallander och Tom Hedelius Foundation, and the National Centre of Competence in Research "Financial Valuation and Risk Management" (NCCR FINRISK) is gratefully acknowledged.

${ }^{1}$ Brennan and Tamarowski (2000) and Bushee and Miller (2008) discuss the role of the investor relations department.
} 
profile, "Our efforts culminate in a broader shareholder base, increased liquidity, a lower future cost of capital, and a better valuation relative to the client's peer group."

Despite the apparent importance of the shareholder base, there is little academic evidence documenting the impact of the shareholder base on corporate decisions. In this paper we investigate the effect of the shareholder base on the level and method of payout. There are several arguments that imply that external financing is costly for firms with small shareholder bases, either due to asymmetric information or lack of visibility. First, the investor base may proxy for the amount of external financing that is available. Merton (1987) argues that the shareholder base measures the recognition of the firm. He develops an incomplete risk sharing model where the size of the firm's investor base is negatively related to the required return on the firm and hence its cost of capital. ${ }^{3}$ In this setting, a small shareholder base implies that a limited fraction of the market is informed about the stock, and hence the firm has a limited number of investors from whom to raise capital. Merton argues that the shareholder base can be expanded (allowing more funds to be raised), but at an increasing cost. ${ }^{4}$

Second, having a large number of shareholders may reduce asymmetric information between insiders and outsiders through more information production. The intuition behind this argument is captured in the model of Holmström and Tirole (1993). In their model, an increase in liquidity trading (the investor base) leads to an increase in stock price informativeness through more information acquisition by speculators. Additionally, empirically it has been documented that analysts tend to follow firms that have more investors. ${ }^{5,6}$ So a large investor base leads to greater analyst coverage and more information production overall, which ultimately implies less asymmetric information about the firm.

Both of the above arguments imply that external financing is costly for firms with small shareholder bases. Effectively, for firms with limited shareholder bases there is a wedge between the internal and external costs of funds. ${ }^{7}$

We develop and test 3 hypotheses concerning the relation between the shareholder base and payout policy using a sample of firms on NYSE, NASDAQ, and AMEX between 1984 and 2004. First, a negative relation between the cost of external financing and the shareholder base implies that we expect firms with small shareholder bases to maintain higher cash reserves and pay out less to their

\footnotetext{
${ }^{2}$ See http://www.wolfeaxelrod.com/profile.htm

${ }^{3}$ There is a growing literature that documents a relationship between investor recognition and the value of the firm. Kadlec and McConnell (1994), Foerster and Karolyi (1999), and King and Segal (2009) consider the effect of listing decisions on the shareholder base and their implications for firm valuation. Additionally, Lehavy and Sloan (2008), Bodnaruk and Östberg (2009), and Fang and Peress (2009) document that there is a cross-sectional relationship between investor recognition and returns and therefore the cost of capital.

${ }^{4}$ Grullon, Kanatas, and Weston (2004) find that firms that have higher advertising expenditure also have a larger number of shareholders, implying that the shareholder base can be expanded at a cost.

${ }^{5}$ See Bhushan and O'Brien (1990).

${ }^{6}$ Additionally, Bjerring, Lakonishok, and Vermaelen (1993), Dimson and Marsh (1984), and Womack (1996) document that analyst forecasts are informative.

${ }^{7}$ Kaplan and Zingales (1997) define a financial constraint as a wedge between the internal and external costs of capital.
} 
shareholders. We find that small shareholder base firms have lower payout levels and larger cash reserves. Firms at the 25th percentile of the shareholder base hold between $4.75 \%$ and $6.38 \%$ more in cash reserves and pay out between $12.32 \%$ and $23.37 \%$ less of their total assets (all relative to the unconditional mean) than firms at the 75 th percentile. We corroborate the above results on payout and cash holdings in an experimental setting by considering the introduction of decimal quotes on the NYSE, NASDAQ, and AMEX in 2001. Decimalization significantly lowered trading costs and thereby raised the demand for shares by retail investors and resulted in larger shareholder bases. This increase in the shareholder base is associated with increased payout and decreased cash holdings.

Second, given that there is a relation between the shareholder base and the cost of external financing, this has a potential implication for the method of payout. A firm considering making a special distribution can do it either in the form of a share repurchase or through a special dividend. However, an open market repurchase program may result in a smaller shareholder base if some shareholders tender all of their shares. We verify this conjecture by demonstrating that a share repurchase program reduces the shareholder base of the firm by at least $3.70 \%$ over the year of repurchase and the subsequent year. In contrast, nonrepurchasing firms experience, on average, a 3.69\% increase in the shareholder base over a 2-year period. Additionally, we find that special dividends either have a neutral or even a positive effect on the shareholder base. Hence, we argue that while repurchases are more tax efficient, they come at a cost of reduction in the shareholder base and therefore higher costs of external financing.

Third, given that a repurchase reduces the size of the shareholder base, we examine whether firms with already limited shareholder bases are less likely to use a repurchase as a payout method and thereby reduce the size of the shareholder base even further. We find that the shareholder base significantly affects the decision to undertake one-time distributions to shareholders and the method of distribution (special dividend or share repurchase). Small shareholder base companies are more likely to pay special dividends. Conditional on undertaking a special distribution, companies with small shareholder bases choose to use a special dividend (rather than repurchase stock) in $9.05 \%$ of cases, while $6.49 \%$ of special distributions of large shareholder base firms are special dividends.

This paper is most closely related to the literature on investor recognition and investor relations. This literature (see footnote 3 ) documents the effect of the shareholder base on firm value and returns. The finding that the size of the shareholder base is negatively related to returns implies that small shareholder base firms have high costs of financing. We contribute to this literature by showing that the shareholder base is also related to payout policy.

A number of papers consider the effect of investor composition on payout policy. For example, Grinstein and Michaely (2005) examine the relation between institutional holdings and payout policy. Among other things, they find that institutions prefer dividend-paying to nondividend-paying firms and firms that repurchase shares. Instead of considering the composition of the firm's investor base, we examine the size of the shareholder base. In fact, our measure of the shareholder base is weakly negatively related to the degree of institutional holdings (the correlation is $-8.8 \%$ ), which makes intuitive sense if institutional 
investors hold larger positions. Nonetheless, we control for institutional holdings in our estimations, and this does not affect our results qualitatively. Additionally, in a robustness section, we demonstrate that our results are independent of investor composition. In essence, the clientele literature considers stock demand by certain investor groups and relates that to payout policy, whereas we consider the relation between total investor demand and payout policy.

Our paper is related to the extensive literature on the level and method of payout. One of the central and most cited determinants of the level of payout is agency costs (Easterbrook (1984), Jensen (1986)). Early work by Rozeff (1982) uses the shareholder base as a proxy for the degree to which the firm is exposed to agency costs. In Rozeff's setting, a firm that has a large shareholder base is also more exposed to agency problems and therefore pays out more as dividends. Rozeff documents a positive correlation between the shareholder base and dividend payout, which is what we find (except that we consider Total Payout). Although the size of the shareholder base may be related to the agency costs of the firm, studies that examine the effect of exogenous increases in the shareholder base (Amihud, Mendelson, and Uno (1999), Sec. IV.C) document that increases in the shareholder base are also associated with price increases. ${ }^{8}$ If the shareholder base only is a proxy for agency costs, then we would expect a price decrease following an exogenous increase in the shareholder base as the agency problem has been aggravated. In our regressions we include a host of control variables that capture agency costs.

Another strand of literature relates financial constraints to the level of payout (e.g., Kaplan and Zingales (1997), Cleary (1999), and Whited and Wu (2006)). This literature uses a set of variables (including whether a firm has a positive dividend payout) to construct measures of the cost of external financing. In contrast, this paper provides evidence that the shareholder base influences the cost of external financing and therefore is related to payout and cash holdings of firms.

Finally, this paper is related to the literature that examines the determinants of the method of payout. ${ }^{9}$ To our knowledge, we are the first to demonstrate that a repurchase adversely affects the shareholder base and that this adverse impact is a possible explanation for why firms pay dividends even though repurchases are more tax efficient. Other potential reasons for undertaking a repurchase rather than a dividend include trading gains by insiders (Barclay and Smith (1988)), improved stock liquidity (Barclay and Smith), flexibility (Stephens and Weisbach (1998)), and maintaining the earnings per share (EPS) in the presence of stock option exercise (Kahle (2002)). ${ }^{10}$

\footnotetext{
${ }^{8}$ See footnote 3 .

${ }^{9}$ Black (1976) coined the term "dividend puzzle," which refers to the fact that dividends represent a substantial proportion of total payout even though repurchases are more tax efficient. To explain this puzzle there has to be some drawback to using a repurchase as a payout method instead of dividends. As we have shown, one difference between repurchases and dividends is that a repurchase reduces the shareholder base while a dividend does not. Therefore, a possible explanation to the dividend puzzle is that firms are reluctant to reduce their shareholder base.

${ }^{10}$ It is noteworthy that the improved liquidity, flexibility, and EPS motives for undertaking a repurchase cannot explain the extensive use of dividends, since they all present advantages of repurchases over dividends.
} 
The remainder of this paper is organized as follows: In Section II, we present testable hypotheses, and we describe our data in Section III. In Section IV, we present empirical findings. We consider the robustness of our results in Section V, and in Section VI we conclude.

\section{Testable Hypotheses}

Our testable hypotheses come from the tenet that there is a negative relation between the size of the shareholder base and the cost of external financing. For example, the model of Holmström and Tirole (1993) can be used to justify why price informativeness is related to the size of the shareholder base. ${ }^{11}$ If a larger shareholder base implies more liquidity traders, then this creates incentives for speculators to acquire more information. This in turn leads to lower asymmetric information and therefore to a lower cost of external financing. Since the shareholder base is related to price informativeness, the wedge between the cost of internal and external funds is decreasing in the size of the shareholder base.

Merton (1987) argues that a good measure of the recognition of a firm is the size of its shareholder base. Likewise, the recognition of a firm is related to the availability of external financing. So a firm with a large shareholder base is widely recognized and therefore has a large pool of investors from whom to raise financing. Merton argues that increasing the shareholder base may be possible, but at a cost that is increasing. Therefore, it is costly for a firm with a limited shareholder base to raise external financing, since this requires a costly increase in the shareholder base (the firm requires more recognition).

The above arguments imply that the wedge between the cost of internal and external financing is negatively related to the size of the shareholder base. Therefore, we expect firms with small shareholder bases to rely more on internal financing. As a result, these firms are expected to pay out less to their shareholders and maintain higher cash reserves. Stated formally,

Hypothesis 1. Firms with small shareholder bases pay out less and hold larger cash reserves.

Since the shareholder base and the cost of external financing are negatively related, a reduction in the shareholder base will make external financing even more expensive, which leads to a lower firm value. Indeed, Brav et al. ((2005), p. 515) report, "Many firms feel that their stock price would fall if they had a less diverse investor base."

The method of payout may have implications for the size of the shareholder base. For example, when a firm undertakes a repurchase, there are two countervailing effects on the size of the shareholder base. On the one hand, the firm generates attention by announcing a repurchase, but on the other hand, if a substantial proportion of shareholders tender their entire stake, then the shareholder

\footnotetext{
${ }^{11}$ Harris ((2003), p. 238) writes: "Informed trading is most profitable in markets with many uninformed traders. In such markets, many informed traders compete to acquire information and act on it. These markets therefore have very informative prices."
} 
base will fall as a result of a repurchase. We anticipate the 2 nd effect to dominate. Hence our 2nd hypothesis:

Hypothesis 2. Share repurchases reduce the size of the shareholder base.

If a repurchase results in a smaller shareholder base, we expect that firms will try to avoid undertaking a repurchase if the shareholder base is already limited (and external financing is expensive). In contrast, a special dividend has no adverse impact on the shareholder base. This leads to the following testable hypothesis:

Hypothesis 3. Firms with small shareholder bases are more likely to pay a special dividend and less likely to undertake a repurchase.

\section{Sample and Variable Construction}

A. Data

Our sample includes firms listed on NYSE, AMEX, and NASDAQ. Data on returns, prices, repurchases, and shares outstanding of stocks are obtained from the Center for Research in Security Prices (CRSP)-Compustat Merged Industrial Database (CCM). We only consider firms with CRSP share codes 10 or 11. Therefore, we exclude American depositary receipts, closed-end funds, real estate investment trusts, and shares of firms incorporated outside the United States. Our main variable of interest is the number of common shareholders of record (Shareholder Base, CCM data 100), hence we exclude firms for which this variable is missing.

We consider the period from 1984 to 2004. The choice of this period is motivated by the introduction of Securities and Exchange Commission (SEC) Rule 10b-18 in 1982, which provides a legal safe harbor for companies repurchasing their shares, greatly reducing the ambiguity associated with this activity. Furthermore, since 1984, firms have been required to report the value of their repurchases in their cash flow statements, and this item can be found in the CCM database as data item 115 .

Our dependent variables are measures of firm cash holdings and payout. We follow Opler, Pinkowitz, Stulz, and Williamson (1999) and define Cash as the ratio of cash to total assets net of cash. Total Payout is defined as the sum of total dividends and repurchases over total assets. We construct our measure of repurchases using the CCM data item Purchase of Common and Preferred Stock (item 115), which reports the amount of money a company spends on repurchasing its own securities. ${ }^{12,13}$ To construct our variable Fraction Repurchased, we divide the dollar value of shares repurchased by market capitalization. We further

\footnotetext{
${ }^{12}$ As a robustness test, we remove repurchases of preferred stock from our measure of repurchases (like in Dittmar (2000) and Weisbenner (2004)). The results are not affected.

${ }^{13}$ Banyi, Dyl, and Kahle (2008) compare the accuracy of different sources of repurchase data and conclude that Compustat purchases of common stock is the most accurate.
} 
screen stock repurchases by setting repurchases equal to 0 for any firm that does not repurchase at least $1 \%$ of its market value of equity (as in Dittmar (2000)).

We draw from DeAngelo, DeAngelo, and Skinner (2000) in identifying special dividends. We classify a cash distribution as a special dividend if it carries distribution code of 1262 or 1272 . These codes are used by CRSP if dividends are labeled year-end, final, extra, or special. We do not include "interim" dividends (code 1282), since they are relatively uncommon in our sample period. We also exclude dividends with distribution code 1292, defined as "nonrecurring, or proceeds from sale of rights," because they generally are not pure cash payouts to stockholders. We set a special dividend dummy (Special Dividend) to 1 if a company has paid a special dividend in a particular year, and 0 otherwise.

In selecting our sample, we omit firms with missing or negative values of Market Capitalization and Book-to-Market $(B M)$. We winsorize all of our variables at the 1st and 99th percentiles. We also remove companies with values of Cash above 0.8. This leaves us with 52,679 firm-year observations, which are the basis for our analysis. ${ }^{14}$

Table 1 presents descriptive statistics of our data. In our sample, firm cash holdings (Cash) are on average $14.62 \%$ of total assets. This is in line with Opler et al. (1999). The average total payout (Total Payout) in our sample is $2.40 \%$ of total assets. The average firm in our sample has 17,150 shareholders of record

\section{TABLE 1}

Descriptive Statistics of the Data

In Table 1, we present descriptive statistics on the variables used in our study. The shareholder base is given in 1,000s. All variables are described in the Appendix. All variables are winsorized at $1 \%$ and $99 \%$ of the distribution.

\begin{tabular}{|c|c|c|c|c|}
\hline Variable & $N$ & Mean & Median & Std. Dev. \\
\hline Shareholder base & 52,679 & 17.15 & 1.83 & 454.88 \\
\hline Market cap (mln) & 52,679 & $1,898.18$ & 180.78 & $10,646.16$ \\
\hline Book-to-market (BM) & 52,679 & 0.68 & 0.55 & 0.58 \\
\hline Price-to-earnings (PE) & 52,679 & 15.88 & 13.72 & 43.99 \\
\hline Debt-to-equity (DE) & 52,679 & 0.76 & 0.34 & 1.46 \\
\hline Operating income & 52,679 & 0.12 & 0.13 & 0.14 \\
\hline$R \& D$ & 52,679 & 0.04 & 0.00 & 0.27 \\
\hline Cash & 52,679 & 0.14 & 0.06 & 0.17 \\
\hline Dividend payout & 52,679 & 0.01 & 0.00 & 0.02 \\
\hline Total payout & 52,679 & 0.02 & 0.01 & 0.04 \\
\hline Stock liquidity & 52,679 & 1.15 & 0.74 & 1.30 \\
\hline Past year return & 52,679 & 0.16 & 0.15 & 0.53 \\
\hline Volatility $(\times 100)$ & 52,679 & 0.68 & 0.39 & 1.15 \\
\hline Capital expenditures (Capex) & 52,679 & 0.07 & 0.05 & 0.07 \\
\hline Firm age & 52,679 & 22.40 & 18.00 & 18.03 \\
\hline ROE & 52,679 & 0.05 & 0.11 & 0.40 \\
\hline Institutional ownership & 52,679 & 0.38 & 0.35 & 0.25 \\
\hline Industry concentration & 52,679 & 0.08 & 0.05 & 0.09 \\
\hline Misvaluation (RRV) & 38,492 & -0.04 & -0.04 & 0.37 \\
\hline Whited-Wu index & 38,492 & -0.19 & -0.19 & 0.14 \\
\hline Managerial ownership & 5,876 & 0.01 & 0.00 & 0.03 \\
\hline Option-based compensation (OBC) & 5,876 & 0.38 & 0.37 & 0.25 \\
\hline Board independence & 5,876 & 0.63 & 0.67 & 0.18 \\
\hline Board size & 5,876 & 1.28 & 1.26 & 0.30 \\
\hline Corporate governance index & 5,876 & 9.28 & 9.00 & 2.66 \\
\hline Share repurchase dummy $(\times 100)$ & 52,679 & 22.66 & 0.00 & 41.87 \\
\hline Special dividend dummy $(\times 100)$ & 52,679 & 1.71 & 0.00 & 12.97 \\
\hline
\end{tabular}

\footnotetext{
${ }^{14}$ As a robustness test, we removed all financial and regulated firms from our sample without affecting our results qualitatively.
} 
(Shareholder Base). However, the median firm has only 1,830 shareholders. To correct for skewness, we use the logarithm of Shareholder Base. Additionally, a repurchase is undertaken in $22.66 \%$ of all firm years. A special dividend is undertaken in $1.71 \%$ of all firm years. In unreported analysis we document a declining trend in the frequency of special dividends. DeAngelo et al. (2000) conclude that this is because firms that undertake special dividends frequently relabel these as regular dividends. However, like DeAngelo et al., we also find that the frequency of "large" specials does not decrease over our sample period.

There are a number of alternative stories that we need to control for. First, Grinstein and Michaely (2005) document that institutions avoid firms that do not pay dividends. However, among dividend payers they prefer firms that pay lower dividends. Institutions also prefer repurchasers and those firms that repurchase regularly. To that end, we include among our control variables the fraction of outstanding equity held by institutions (Institutional Ownership), which we calculate from $13 \mathrm{~F}$ filings that are included in the CDA/Spectrum database.

Second, several papers document that undervaluation is an important motive for undertaking a repurchase (e.g., Ikenberry, Lakonishok, and Vermaelen (1995), (2000)). It could well be that firms with large shareholder bases are undervalued and therefore repurchase more often. We control for the undervaluation motive by including the book-to-market ratio, the stock performance during the previous year, and the Rhodes-Kropf, Robinson, and Viswanathan (RRV) (2007) measure of misvaluation in our estimations.

Third, since we argue that a small shareholder base creates a wedge between the costs of internal and external funds, our paper is related to the literature on financial constraints. To control for traditional measures of financial constraints, we include the Whited and $\mathrm{Wu}$ (2006) index (Whited-Wu) in our regressions. ${ }^{15}$

Fourth, Barclay and Smith (1988) argue that one reason to avoid undertaking a repurchase is that this may harm stock liquidity. They find that the bid-ask spread widens around repurchase announcements. ${ }^{16}$ Using detailed buyback data from Hong Kong, Brockman and Chung (2001) find that the bid-ask spread widens and the depth narrows during repurchase periods. However, they also find that the spread and the depth return to benchmark levels once managers disclose that they are the source of the trading. ${ }^{17,18}$ Nevertheless, we control for liquidity by considering the volume of shares traded over the past year divided by the number of shares outstanding (Stock Liquidity).

Fifth, a large shareholder base may indicate that ownership is dispersed and therefore firms with large shareholder bases might be more exposed to agency problems. If large shareholder base firms are more exposed to agency problems,

\footnotetext{
${ }^{15}$ In unreported results, we have also included the Kaplan and Zingales (1997) index in our estimations without affecting our results qualitatively.

${ }^{16}$ Miller and McConnell (1995) find no evidence of a widening in bid-ask spread when considering a different sample and methodology.

${ }^{17}$ Grullon and Ikenberry (2000) find that firms that are actively repurchasing are less sensitive to market movements in a bearish market.

${ }^{18}$ In a study of U.S. repurchases, Cook, Krigman, and Leach (2004) find that liquidity increases after a repurchase, and they attribute this result to the difference in the disclosure environment between Hong Kong and the United States.
} 
we would expect them to pay out less to investors. To control for differences in agency costs across firms, we consider the fraction of shares owned by the top 5 company executives (Managerial Ownership). Additionally, we control for differences in incentives provided to executives by including the proportion of total compensation to the management of the firm paid in the form of stock options (Option-Based Compensation). Including this variable in our analysis also ensures that our results are not driven by repurchases that are undertaken to offset stock grants and option exercises by firm managers. These measures are calculated from the Thompson/Reuters Insider Database. A number of studies examine the relation between firm governance and cash holdings (e.g., Dittmar and Mahrt-Smith (2007), Harford, Mansi, and Maxwell (2008)). We therefore include the Gompers, Ishii, and Metrick (2003) governance index $(G)$ as a control variable. We also include Board Size and Board Independence as controls. The board controls as well as the Gompers et al. index are obtained from the Investor Responsibility Research Center (IRRC).

Last, Hovakimian, Opler, and Titman (2001) document that one motive for undertaking a repurchase is to alter the firm's capital structure. To that end, we include the Debt-to-Equity ( $D E$ ) ratio when determining the factors that influence the decision of undertaking a repurchase or paying a special dividend.

We provide a detailed description of the variables in the Appendix.

\section{B. Excess Shareholder Base}

Grullon et al. (2004) note that there is a strong relation between the Number of Common Shareholders and variables such as Market Capitalization and Age. In order to ensure that our results are not driven by other firm characteristics that are not directly related to the recognition of the firm, we remove the effect of a number of variables on the Number of Common Shareholders. In all subsequent analysis we use the residuals from this regression, which we call Excess Shareholder Base (ExShBase), as our measure of the shareholder base. ${ }^{19}$ In a different context, Hong, Kubik, and Stein (2009) estimate a similar regression and use the residuals as a measure of firm visibility.

Table 2 presents our regression results. For each of the 22 years in our sample, we estimate a cross-sectional regression where the dependent variable is the logarithm of the Number of Common Shareholders, and then we report the average of all the estimates. We follow Grullon et al. (2004) and include Age, Return on Equity, Market Capitalization, 1/Share Price, Stock Liquidity, Past Year Return, and Volatility as explanatory variables. It is important to account for size, since even though larger firms have more press coverage and larger analyst following, which is associated with larger recognition, they also have more shares available to buy. Illiquid stocks might have fewer shareholders due to the large transaction costs associated with trading them and not due to recognition. Therefore, to control for transaction costs we include both $1 /$ Share Price and the volume-based liquidity measure Stock Liquidity. Both Age and Volatility control

\footnotetext{
${ }^{19}$ Bodnaruk and Östberg (2009) document that the residual shareholder base is negatively related to returns.
} 
for total risk of the firm. Firms that have performed well recently might have a lot of investors, but this does not necessarily represent a permanent firm characteristic. To that end, we include Return on Equity and Past Year Return to control for the effect of recent performance on the shareholder base.$^{20}$ Certain investors might only invest in "value" or "glamour" stocks, and therefore we include $B M$ into our specifications as a control for firm type.

\section{TABLE 2}

Determinants of Shareholder Base

\begin{tabular}{|c|c|c|}
\hline log(Shareholder Base) & Estimate & $\underline{p \text {-Value }}$ \\
\hline $\begin{array}{l}\text { log(Firm age) } \\
\text { ROE } \\
\text { log(Market cap) } \\
\text { log(BM) } \\
1 / \text { Share price } \\
\text { Stock liquidity } \\
\text { Past year return } \\
\text { Volatility }\end{array}$ & $\begin{array}{r}0.40 \\
-0.17 \\
0.63 \\
0.23 \\
1.49 \\
0.01 \\
-0.07 \\
5.01\end{array}$ & $\begin{array}{l}(0.01) \\
(0.01) \\
(0.01) \\
(0.01) \\
(0.01) \\
(0.72) \\
(0.01) \\
(0.01)\end{array}$ \\
\hline $\begin{array}{l}\text { Exchange dummies } \\
\text { Industry dummies } \\
\text { Clustering } \\
\text { Adj. } R^{2} \\
N\end{array}$ & \multicolumn{2}{|c|}{$\begin{array}{l}\text { Yes } \\
\text { Yes } \\
\text { SIC2 } \\
0.431 \\
22\end{array}$} \\
\hline
\end{tabular}

The regression results are qualitatively similar to what Grullon et al. (2004) find. Large, value, and older firms have more shareholders. Additionally, firms that are cheap to trade (that have a high $1 /$ Share Price) also have more shareholders. Firms with good recent performance (both in terms of Return on Equity and Past Year Return) have fewer shareholders. Grullon et al. point out that this finding is consistent with the "disposition effect" whereby investors hold on to past losers and sell winners.

We define ExShBase as the residual from this regression and employ it as our measure of recognition throughout the rest of our study. A firm that has a positive ExShBase (residual) has a larger shareholder base than expected according to its fundamentals. Using ExShBase instead of Number of Common Shareholders does not alter the direction of the effects that we measure, but in general it reduces the economic magnitude of the effects measured.

For the shareholder base to be related to the cost of external financing, it is important that having a small shareholder base is a persistent characteristic. If this is not the case, then a firm with a small shareholder base can just wait until its shareholder base returns to normal levels.

To examine whether the shareholder base is persistent, we split firms into quartiles on the basis of ExShBase. Firms in quartile 4 have the largest shareholder bases, adjusting for their fundamentals. We identify when a firm enters the largest

\footnotetext{
${ }^{20}$ Unlike Grullon et al. (2004), we do not include advertising expenditure in our regressions. First, it is likely to be highly related to the recognition that the firms have by individual investors. Second, including a measure of advertising expenditure would result in a tenfold decrease in sample size.
} 
quartile for the first time, and we record which quartile these firms belong to over the subsequent 5 -year period. ${ }^{21}$ The results are provided in Table 3. After 5 years, $56.5 \%$ of firms originally falling into the quartile with the largest shareholder bases still belong to this quartile. Another $31.1 \%$ have migrated to quartile 3 , which implies that $87.6 \%$ of firms originally in quartile 4 still have a shareholder base that is larger than what is expected according to their fundamentals. The results are similar for firms that have the smallest shareholder bases (quartile 1). After 5 years, $51.9 \%$ of quartile 1 firms still belong to quartile 1 . In total, $82.8 \%$ of quartile 1 firms still belong to quartile 1 or 2 after 5 years. Thus, having a small or large shareholder base seems to be a persistent firm characteristic.

TABLE 3

Persistence of Excess Shareholder Base

In Table 3, we report the results on the persistence of excess shareholder base for firms that are selected when they enter the highest (lowest) quartile of excess shareholder base for the first time. Excess shareholder base is the residual of the regression reported in Table 2. Firms are followed for 5 years to determine which quartile they belong in the subsequent year. Quartile 4 represents the highest excess shareholder base quartile, and Year 0 is the measurement year. Numbers shown are percentages. The number of firms is in square brackets. We require companies to have nonmissing excess shareholder base for the years -1 to +5 relative to the measurement year.

Quartile

\begin{tabular}{|c|c|c|c|c|}
\hline \multirow[b]{2}{*}{ Year } & \multicolumn{4}{|c|}{ Quartile } \\
\hline & 4 & 3 & 2 & 1 \\
\hline \multicolumn{5}{|c|}{$\begin{array}{l}\text { Panel A. Persistence of Excess Shareholder Base for Firms That Are in the Highest Quartile of Excess Shareholder Base } \\
\text { in Year } 0\end{array}$} \\
\hline 0 & $\begin{array}{l}1.00 \\
{[563]}\end{array}$ & & & \\
\hline 1 & $\begin{array}{c}0.68 \\
{[383]}\end{array}$ & $\begin{array}{c}0.29 \\
{[162]}\end{array}$ & $\begin{array}{l}0.02 \\
{[13]}\end{array}$ & $\begin{array}{c}0.01 \\
{[5]}\end{array}$ \\
\hline 2 & $\begin{array}{c}0.61 \\
{[346]}\end{array}$ & $\begin{array}{c}0.32 \\
{[179]}\end{array}$ & $\begin{array}{l}0.05 \\
{[27]}\end{array}$ & $\begin{array}{l}0.02 \\
{[11]}\end{array}$ \\
\hline 3 & $\begin{array}{l}0.57 \\
{[322]}\end{array}$ & $\begin{array}{c}0.34 \\
{[192]}\end{array}$ & $\begin{array}{l}0.06 \\
{[32]}\end{array}$ & $\begin{array}{l}0.03 \\
{[17]}\end{array}$ \\
\hline 4 & $\begin{array}{c}0.58 \\
{[326]}\end{array}$ & $\begin{array}{c}0.32 \\
{[179]}\end{array}$ & $\begin{array}{l}0.07 \\
{[38]}\end{array}$ & $\begin{array}{l}0.03 \\
{[20]}\end{array}$ \\
\hline 5 & $\begin{array}{c}0.57 \\
{[318]}\end{array}$ & $\begin{array}{c}0.31 \\
{[175]}\end{array}$ & $\begin{array}{l}0.08 \\
{[45]}\end{array}$ & $\begin{array}{l}0.04 \\
{[25]}\end{array}$ \\
\hline
\end{tabular}

Panel B. Persistence of Excess Shareholder Base for Firms That Are in the Lowest Quartile of Excess Shareholder Base

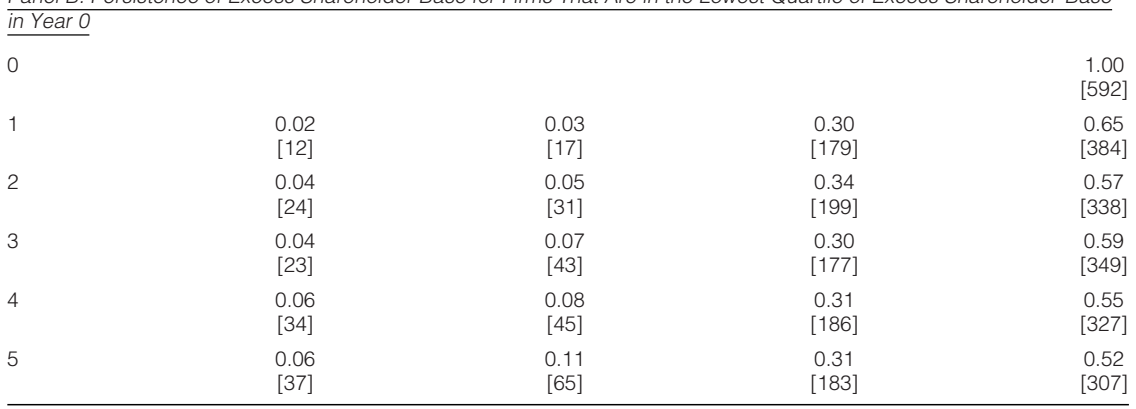

\footnotetext{
${ }^{21}$ We restrict our analysis to firms with at least 5 years of uninterrupted values of ExShBase following entering the highest (lowest) quartile of ExShBase. This restriction does not affect our results in any significant way.
} 


\title{
IV. Results
}

\section{A. The Shareholder Base and Payout}

Firms with negative values of ExShBase have smaller shareholder bases than implied by their fundamental characteristics. Following Hypothesis 1, we expect these firms to have high costs of external financing and therefore to pay out less. In Panel A of Table 4 we provide univariate evidence on the relation between ExShBase and Total Payout. Companies with negative values of ExShBase pay out on average $2.21 \%$, while firms with positive values pay out on average $2.59 \%$ (or $17.19 \%$ more) of their total assets. Additionally, when we only consider firms with positive values of Total Payout, small shareholder base firms pay out on average $3.50 \%$ and large shareholder base firms pay out $3.89 \%$ (or $11.14 \%$ more) of their total assets. These differences are statistically significant at the $1 \%$ level.

In Panel B of Table 4 we restrict the Total Payout to be between 0\%-100\% of net income. This selection reduces the average payout significantly. Firms with positive values of ExShBase pay out $1.55 \%$ of total assets, whereas firms with negative values pay out $1.41 \%$ (positive ExShBase firms payout $9.93 \%$ more). The difference is statistically significant.

Panel $\mathrm{C}$ of Table 4 reports the results from our multivariate analysis with Total Payout as the dependent variable. Specifications 1 and 2 are

\section{TABLE 4}

\section{Shareholder Base and Total Payout}

\begin{abstract}
In Table 4, we investigate the relation between the excess shareholder base and total payout. We utilize the residuals from the regression reported in Table 2 as our measure of the shareholder base. The dependent variable is next year total payout, defined as the sum of dividends and repurchases divided by total assets. All variables are described in the Appendix. Panel A reports the results of univariate analysis both for the full sample and for the sample of companies with positive total payout. In Panel B we report the results of univariate analysis restricting total payout to be within 0\% and $100 \%$ of net income. Panel C reports the results of Tobit regressions. Specifications 1 and 2 are Fama-MacBeth (1973) regressions with industry fixed effects. For each year we estimate a Tobit regression with Total Payout as a dependent variable. We report average regression coefficients. The reported p-values (in parentheses) are based on Newey-West (1987) (2 lags) corrected standard errors of the estimated average regression coefficients. Specifications 3-7 are panel regressions with industry (SIC2) and time fixed effects with standard errors clustered at industry level. All estimates are multiplied by 100.
\end{abstract}

Panel A. Univariate Analysis: All Payouts

\begin{tabular}{|c|c|c|c|}
\hline \multirow[b]{2}{*}{ Excess Shareholder Base } & \multicolumn{3}{|c|}{ Total Payout } \\
\hline & $N$ & Mean & Median \\
\hline \multirow{4}{*}{$\begin{array}{l}\text { High (positive) } \\
\text { Low (negative) }\end{array}$} & 26,506 & $2.59 \%$ & $0.91 \%$ \\
\hline & 26,173 & $2.21 \%$ & $0.64 \%$ \\
\hline & & $\begin{array}{c}t \text {-Stat/ } \\
p \text {-Value }\end{array}$ & $\begin{array}{c}\text { Wilcoxon/ } \\
p \text {-Value }\end{array}$ \\
\hline & & $\begin{array}{c}10.16 \\
(0.01)\end{array}$ & $\begin{array}{c}12.09 \\
(0.01)\end{array}$ \\
\hline
\end{tabular}

Panel B. Univariate Analysis: Payout between $0 \%$ and $100 \%$ of Net Income

\begin{tabular}{|c|c|c|c|}
\hline \multirow[b]{2}{*}{ Excess Shareholder Base } & \multicolumn{3}{|c|}{ Total Payout } \\
\hline & N & Mean & Median \\
\hline \multirow{3}{*}{$\begin{array}{l}\text { High (positive) } \\
\text { Low (negative) }\end{array}$} & 20,580 & $1.55 \%$ & $0.38 \%$ \\
\hline & & $\begin{array}{c}\text { t-Stat/ } \\
p \text {-Value }\end{array}$ & $\begin{array}{c}\text { Wilcoxon/ } \\
p \text {-Value }\end{array}$ \\
\hline & & $\begin{array}{c}5.27 \\
(0.01)\end{array}$ & $\begin{array}{c}5.97 \\
(0.01)\end{array}$ \\
\hline
\end{tabular}

\begin{tabular}{|c|c|c|}
\hline \multicolumn{3}{|c|}{ Total Payout $(>0)$} \\
\hline$N$ & Mean & Median \\
\hline \multirow{4}{*}{$\begin{array}{l}17,688 \\
16,506\end{array}$} & $3.89 \%$ & $2.20 \%$ \\
\hline & $3.50 \%$ & $1.91 \%$ \\
\hline & $\begin{array}{c}t \text {-Stat/ } \\
p \text {-Value }\end{array}$ & $\begin{array}{c}\text { Wilcoxon/ } \\
p \text {-Value }\end{array}$ \\
\hline & $\begin{array}{c}7.23 \\
(0.01)\end{array}$ & $\begin{array}{c}8.69 \\
(0.01)\end{array}$ \\
\hline
\end{tabular}

\begin{tabular}{|c|c|c|}
\hline \multicolumn{3}{|c|}{ Total Payout $(>0)$} \\
\hline$N$ & Mean & Median \\
\hline \multirow{4}{*}{$\begin{array}{l}11,763 \\
11,914\end{array}$} & $2.70 \%$ & $1.86 \%$ \\
\hline & $2.56 \%$ & $1.69 \%$ \\
\hline & $\begin{array}{c}\text { t-Stat/ } \\
\text { p-Value }\end{array}$ & $\begin{array}{c}\text { Wilcoxon/ } \\
p \text {-Value }\end{array}$ \\
\hline & $\begin{array}{c}3.75 \\
(0.01)\end{array}$ & $\begin{array}{c}5.35 \\
(0.01)\end{array}$ \\
\hline
\end{tabular}

(continued on next page) 
TABLE 4 (continued)

Shareholder Base and Total Payout

\begin{tabular}{|c|c|c|c|c|c|c|c|c|c|c|c|c|c|c|}
\hline \multicolumn{15}{|l|}{ Panel C. Multivariate Regressions } \\
\hline \multirow[b]{3}{*}{ Total Payout } & \multicolumn{4}{|c|}{ Fama-MacBeth } & \multicolumn{10}{|c|}{ Pooled Panel } \\
\hline & \multicolumn{2}{|c|}{1} & \multicolumn{2}{|c|}{2} & \multicolumn{2}{|c|}{3} & \multicolumn{2}{|c|}{4} & \multicolumn{2}{|c|}{5} & \multicolumn{2}{|c|}{6} & \multicolumn{2}{|c|}{7} \\
\hline & Estimate & $p$-Value & Estimate & $p$-Value & Estimate & $p$-Value & Estimate & $p$-Value & Estimate & $p$-Value & Estimate & $p$-Value & Estimate & $p$-Value \\
\hline \multirow{2}{*}{$\begin{array}{l}\text { ExShBase } \\
\text { ExShBase }^{2} \\
\times \text { Need external financing } \\
\times \text { No need external financing }\end{array}$} & 0.29 & $(0.01)$ & & & 0.43 & $(0.01)$ & $\begin{array}{r}0.43 \\
-0.13\end{array}$ & $\begin{array}{l}(0.01) \\
(0.01)\end{array}$ & & & 0.31 & $(0.01)$ & 0.20 & $(0.05)$ \\
\hline & & & $\begin{array}{l}0.18 \\
0.34\end{array}$ & $\begin{array}{l}(0.01) \\
(0.01)\end{array}$ & & & & & $\begin{array}{l}0.28 \\
0.50\end{array}$ & $\begin{array}{l}(0.01) \\
(0.01)\end{array}$ & & & & \\
\hline log(Market cap) & 0.15 & $(0.01)$ & 0.14 & $(0.01)$ & 0.49 & $(0.01)$ & 0.50 & $(0.01)$ & 0.49 & $(0.01)$ & 0.04 & $(0.70)$ & 0.42 & $(0.01)$ \\
\hline $\log (B M)$ & -1.14 & $(0.01)$ & -1.14 & $(0.01)$ & -0.75 & $(0.01)$ & -0.75 & $(0.01)$ & -0.75 & $(0.01)$ & -1.47 & $(0.01)$ & -2.24 & $(0.01)$ \\
\hline $\mathrm{DE}$ & -0.32 & $(0.01)$ & -0.32 & $(0.01)$ & -0.36 & $(0.01)$ & -0.36 & $(0.01)$ & -0.36 & $(0.01)$ & -0.28 & $(0.01)$ & -0.42 & $(0.01)$ \\
\hline $\mathrm{PE}$ & -0.00 & $(0.01)$ & -0.00 & $(0.01)$ & -0.00 & $(0.01)$ & -0.00 & $(0.01)$ & -0.00 & $(0.01)$ & -0.00 & $(0.01)$ & -0.00 & $(0.01)$ \\
\hline Operating income & 7.75 & $(0.01)$ & 7.76 & $(0.01)$ & 13.73 & $(0.01)$ & 13.71 & $(0.01)$ & 13.82 & $(0.01)$ & 11.36 & $(0.01)$ & 24.33 & $(0.01)$ \\
\hline$R \& D$ & 0.89 & $(0.01)$ & 0.89 & $(0.01)$ & 0.92 & $(0.01)$ & 0.92 & $(0.01)$ & 0.92 & $(0.01)$ & 0.85 & $(0.01)$ & 4.86 & $(0.01)$ \\
\hline Cash & 1.38 & $(0.01)$ & 1.37 & $(0.01)$ & 2.11 & $(0.01)$ & 2.13 & $(0.01)$ & 2.11 & $(0.01)$ & 2.43 & $(0.01)$ & 4.03 & $(0.01)$ \\
\hline Past year return & -0.95 & $(0.01)$ & -0.95 & $(0.01)$ & -1.28 & $(0.01)$ & -1.29 & $(0.01)$ & -1.28 & $(0.01)$ & -1.36 & $(0.01)$ & -1.91 & $(0.01)$ \\
\hline Volatility & -16.73 & $(0.01)$ & 16.80 & $(0.01)$ & -57.09 & $(0.01)$ & -56.32 & $(0.01)$ & -57.16 & $(0.01)$ & -45.21 & $(0.01)$ & -94.36 & $(0.01)$ \\
\hline Capex & -4.76 & $(0.01)$ & -4.76 & $(0.01)$ & -8.38 & $(0.01)$ & -8.43 & $(0.01)$ & -8.37 & $(0.01)$ & -10.05 & $(0.01)$ & -19.03 & $(0.01)$ \\
\hline Institutional ownership & 0.20 & $(0.41)$ & 0.19 & $(0.44)$ & 0.37 & $(0.37)$ & 0.28 & $(0.62)$ & 0.36 & $(0.38)$ & 0.63 & $(0.08)$ & -1.32 & $(0.01)$ \\
\hline Industry concentration & -1.94 & $(0.31)$ & -1.52 & $(0.42)$ & -0.08 & $(0.95)$ & -0.02 & $(0.99)$ & -0.01 & $(0.94)$ & -0.10 & $(0.50)$ & -0.98 & $(0.68)$ \\
\hline Stock liquidity & -0.40 & $(0.01)$ & -0.40 & $(0.01)$ & -0.64 & $(0.01)$ & -0.62 & $(0.01)$ & -0.64 & $(0.01)$ & -0.55 & $(0.01)$ & -0.41 & $(0.01)$ \\
\hline $\begin{array}{l}\text { Misvaluation (RRV) } \\
\text { Whited-Wu index }\end{array}$ & & & & & & & & & & & -1.28 & $(0.01)$ & -0.35 & $\begin{array}{l}(0.30) \\
(0.01)\end{array}$ \\
\hline $\begin{array}{l}\text { Whited-Wu index } \\
\text { Managerial ownership }\end{array}$ & & & & & & & & & & & -12.53 & & $\begin{array}{r}-11.36 \\
-839\end{array}$ & $\begin{array}{l}(0.01) \\
(0.01)\end{array}$ \\
\hline & & & & & & & & & & & & & 0.37 & $(0.47)$ \\
\hline Board independence & & & & & & & & & & & & & 0.37 & $(0.46)$ \\
\hline Board size & & & & & & & & & & & & & 0.77 & $(0.06)$ \\
\hline G-index & & & & & & & & & & & & & 0.00 & $(0.99)$ \\
\hline \multirow{5}{*}{$\begin{array}{l}\text { Industry dummies } \\
\text { Time dummies } \\
\text { Clustering } \\
\text { Adj. } R^{2} \\
N\end{array}$} & \multirow{5}{*}{\multicolumn{2}{|c|}{ Yes }} & \multirow{4}{*}{\multicolumn{2}{|c|}{ Yes }} & \multirow{5}{*}{\multicolumn{2}{|c|}{$\begin{array}{l}\text { Yes } \\
\text { Yes } \\
\text { SIC2 } \\
0.189 \\
52679\end{array}$}} & \multirow{5}{*}{\multicolumn{2}{|c|}{$\begin{array}{l}\text { Yes } \\
\text { Yes } \\
\text { SIC2 } \\
0.191 \\
52,679\end{array}$}} & \multirow{5}{*}{\multicolumn{2}{|c|}{$\begin{array}{c}\text { Yes } \\
\text { Yes } \\
\text { SIC2 } \\
0.189 \\
52,679\end{array}$}} & \multirow{5}{*}{\multicolumn{2}{|c|}{$\begin{array}{c}\text { Yes } \\
\text { Yes } \\
\text { SIC2 } \\
0.238 \\
38,492\end{array}$}} & \multirow{5}{*}{\multicolumn{2}{|c|}{$\begin{array}{l}\text { Yes } \\
\text { Yes } \\
\text { SIC2 } \\
0.229 \\
5,876\end{array}$}} \\
\hline & & & & & & & & & & & & & & \\
\hline & & & & & & & & & & & & & & \\
\hline & & & & & & & & & & & & & & \\
\hline & & & & & & & & & & & & & & \\
\hline
\end{tabular}


Fama-MacBeth (1973) regressions with industry fixed effects. For each year we estimate a Tobit regression with Total Payout as a dependent variable. We report average regression coefficients. The reported $p$-values (in parentheses) are based on Newey-West (1987) (2 lags) corrected standard errors of the estimated average regressions coefficients.

The rest of the specifications are pooled panel Tobit regressions with time and industry fixed effects with standard errors that are clustered at industry (SIC2) level. Neyman and Scott (1948) document that maximum likelihood estimation with fixed effects results in an "incidental parameter problem." In a recent contribution Greene (2004a) documents that in Tobit regressions the incidental parameter problem is small when $T$ is 5 . Given that in our case $T$ is equal to 21 , and that univariate and Fama-MacBeth (1973) results corroborate our Tobit results, we are comfortable that our results are not driven by econometric errors. ${ }^{22}$

Specification 3 includes ExShBase $e^{2}$ in order to capture nonlinearities in the relation between the shareholder base and payout. In all of our specifications ExShBase is significantly positively related to Total Payout.

In terms of relative economic impact, considering specification 3 the impact of ExShBase is roughly 53\% the impact of Market Capitalization and $82 \%$ the impact of $B M$. Specification 6 illustrates that the impact of the shareholder base on payout is greater than that of governance variables like Board Size, Board Independence, and G-index.

In specification 4, going from the 25th to the 50th percentile of ExShBase increases Total Payout by $0.39 \%$. However, going from the 50th to the 75 th percentile of ExShBase only increases Total Payout by $0.24 \%$. This indicates that the relation between the shareholder base and payout is stronger the smaller the shareholder base is and is consistent with the hypothesis that financial constraints are more binding for firms with smaller shareholder bases.

Arguably, the relation between the shareholder base and payout should be attenuated for firms that have a need for external financing. Fazzari, Hubbard, and Petersen (1988) demonstrate that firms in need of external financing will not pay out any dividend regardless of their degree of financial constraints. Intuitively, a firm that has a need for financing will invest its earnings rather than retain the earnings or distribute them to shareholders irrespective of the size of the shareholder base.

To test this, we estimate the need for external financing as done by DemirgüçKunt and Maksimovic (1998) and Durnev and Kim (2005). We define the external financing need as the difference between the firm's actual growth rate and the sustainable growth rate. We estimate the actual growth rate as the prior 2-year geometric average of annual growth rate in total assets. We estimate the sustainable growth rate as the 2-year average of $R O E_{t} /\left(1-R O E_{t}\right)$, where $R O E_{t}$ is the firm return on equity in year $t$.

We define a dummy variable, Need External Financing, that takes the value of 1 if the growth of total assets is greater than the sustainable growth rate $\left(R O E_{t}\right)$

\footnotetext{
${ }^{22}$ Greene (2004b) documents that the incidental parameter problem is larger for probit regressions (which we use in Section IV.E). However, he benchmarks the fixed effect, pooled, and random effect estimators in a probit setting and concludes (p. 111), "It seems likely based on this and all the preceding results that for $T$ larger than 8 , the results will probably favour the fixed-effects estimator."
} 
$\left.\left(1-R O E_{t}\right)\right)$ and 0 otherwise. ${ }^{23}$ In our sample $32.67 \%$ of firms are in need of external financing. Specifications 2 and 5 interact our variable ExShBase with the dummy variable Need External Financing and its complement. In both specifications we find that the effect of the shareholder base is significantly larger for firms that do not need external financing.

Turning to the control variables, as expected, variables that capture the amount of funds available to the firm, such as Cash and Operating Income, are positively related to the payout level. Additionally, variables that capture outflows from the firm, such as the $D E$ ratio and Capex, are negatively related to payout, illustrating that there is a trade-off in the use of funds. Companies with higher return volatility and overvalued companies seem to have lower payout levels. Additionally, firms that are more financially constrained according to the Whited-Wu index pay out less. The inclusion of the Whited-Wu index, Institutional Ownership, and Industry Concentration does not affect our results in any significant way. Also, the inclusion of corporate governance variables G-index, Board Size, and Board Independence does not affect our conclusion that the shareholder base is positively related to Total Payout. Overall, these results support the hypothesis that the shareholder base is positively and statistically significantly related to payout.

\section{B. The Shareholder Base and Cash Holdings}

Panel A of Table 5 presents univariate results of the relation between ExShBase and Cash. Companies with small shareholder bases (negative ExShBase)

\section{TABLE 5}

\section{Shareholder Base and Cash Holdings}

In Table 5, we investigate the relation between the excess shareholder base and cash holdings. We utilize the residuals from the regression reported in Table 2 as our measure of the shareholder base. The dependent variable is cash holdings at the end of the next fiscal year divided by total assets net of cash. All variables are described in the Appendix. In Panel A we report the results of univariate analysis. Panel B reports multivariate regression results. Specifications 1 and 2 are Fama-MacBeth (1973) regressions with industry fixed effects. For each year we estimate an ordinary least squares (OLS) regression with Cash as a dependent variable. We report average regression coefficients. The reported $p$-values (in parentheses) are based on Newey-West (1987) (2 lags) corrected standard errors of the estimated average regression coefficients. Specifications 3-7 are panel regressions with industry (SIC2) and time fixed effects with standard errors clustered at industry level. All estimates are multiplied by 100.

Panel A. Univariate Analysis

\begin{tabular}{|c|c|c|c|}
\hline \multirow[b]{2}{*}{ ExShBase } & \multicolumn{3}{|c|}{ Cash Holdings } \\
\hline & $N$ & Mean & Median \\
\hline \multirow{4}{*}{$\begin{array}{l}\text { High (positive) } \\
\text { Low (negative) }\end{array}$} & 28,058 & $12.76 \%$ & $5.39 \%$ \\
\hline & 27,891 & $16.48 \%$ & $7.02 \%$ \\
\hline & & $t$-Stat/p-Value & Wilcoxon/p-Value \\
\hline & & $\begin{array}{l}14.04 \\
(0.01)\end{array}$ & $\begin{array}{l}13.92 \\
(0.01)\end{array}$ \\
\hline
\end{tabular}

(continued on next page)

\footnotetext{
${ }^{23}$ We choose $R O E_{t} /\left(1-R O E_{t}\right)$ rather than $R O L T C_{t} /\left(1-R O L T C_{t}\right)$ (where $R O L T C$ is the return on long-term capital) or $\left(R O A_{t} \times b_{t}\right) /\left(1-R O A_{t} \times b_{t}\right)$ (where $R O A$ is the return on assets and $b$ is the fraction of earnings retained for investment) since we are interested in the relation between the need for financing and payout to equity holders. See Demirgüç-Kunt and Maksimovic (1998) for a lengthier description of the alternative measures of the need for financing.
} 
TABLE 5 (continued)

Shareholder Base and Cash Holdings

Panel B. Multivariate Regressions

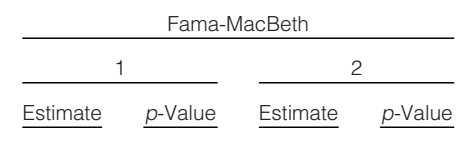

ExShBase

ExShBase
$\times$ Need external financing

$\times$ No need external financin

$\log$ (Market cap)

$\log (B M)$

DE

Operating income

R\&D

Total payout

Past year return

Volatility

Institutional ownership

Industry concentration

Stock liquidity

Misvaluation (RRV)

Whited-Wu index

$\mathrm{OBC}$

Board independence

Board size

Industry dummies

Time dummies

Clustering

Adj. $R^{2}$

N$$
\text { (0.01) }
$$

$$
-0.350 .01)
$$$$
-1.0+100
$$

-1.01
-3.99

-3.99
-2.13

0.00
1.00
14.81

14.81
21.99
-0.03

-0.03
-43.41

-22.04
-2.36

-2.36
29.23
2.71

$2.71 \quad(0.18)$

-0.35
-0.76
-1.01
-4.00
-2.12
0.00
0.96
14.82
21.95
-0.03
-44.18
-22.04
-2.32
44.86
2.72

$(0.01)$

$\begin{array}{lllll}(0.01) & & & & \\ (0.01) & -0.94 & (0.01) & -0.95 & (0.01)\end{array}$

$\begin{array}{llll}(0.01) & -4.00 & (0.01) & -4.00\end{array}$

$\begin{array}{llll}(0.01) & -2.11 & (0.01) & -2.12 \\ (0.45) & -0.00 & (0.40) & -0.00\end{array}$

$\begin{array}{llll}(0.75) & -2.17 & (0.08) & -2.14\end{array}$

$(0.01)$

6.97

$\begin{array}{rrrr}(-0.08) & -0.18 & (0.30) & -0.17 \\ (0.01) & -14.20 & (0.21) & -14.59\end{array}$

$\begin{array}{llll}(0.01) & -20.13 & (0.01) & -20.12\end{array}$

$(0.01) \quad-2.58$

$(0.11)$

$(0.11)$
$(0.01)$ $\begin{array}{rr}(0.01) & -2.97 \\ (0.01) & 21.65 \\ (0.30) & -0.17\end{array}$

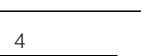

Pooled Panel

$\frac{5}{\underline{\text { Estimate }} \quad \underline{p \text {-Value }}} \frac{6}{\underline{\text { Estimate }} \quad \underline{p \text {-Value }}} \frac{7}{\underline{\text { Estimate }} \quad \underline{p \text {-Value }}}$

$-0.39$

$-0.61 \quad(0.01)$

$\begin{array}{ll}-0.94 & (0.01) \\ -4.01 & (0.01)\end{array}$

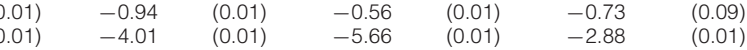

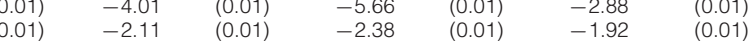

$\begin{array}{lllllll}(0.42) & -0.00 & (0.40) & -0.00 & (0.45) & -0.00 & (0.39)\end{array}$

$\begin{array}{lrrrrrr}(0.08) & -2.19 & (0.08) & -3.01 & (0.10) & 10.24 & (0.15) \\ (0.01) & 6.96 & (0.01) & 8.73 & (0.01) & 25.83 & (0.02)\end{array}$

$\begin{array}{rrrrrrr}(0.01) & 6.96 & (0.01) & 8.73 & (0.01) & 25.83 & (0.02) \\ (0.01) & 21.57 & (0.01) & 25.06 & (0.01) & 30.78 & (0.01)\end{array}$

$\begin{array}{rrrrrrr}(0.01) & 21.57 & (0.01) & 25.06 & (0.01) & 30.78 & (0.01) \\ (0.34) & -0.18 & (0.30) & -0.23 & (0.35) & 0.80 & (0.33)\end{array}$

$\begin{array}{lllllll}(0.22) & -14.04 & (0.21) & -10.96 & (0.45) & 39.25 & (0.62)\end{array}$

$\begin{array}{lllllll}(0.01) & -20.12 & (0.01) & -20.30 & (0.01) & -28.17 & (0.01)\end{array}$

$\begin{array}{rrrrrrr}(0.01) & -2.58 & (0.01) & -3.12 & (0.01) & -7.39 & (-0.01) \\ (0.31) & 3.49 & (0.36) & 4.59 & (0.09) & 11.23 & (0.34)\end{array}$

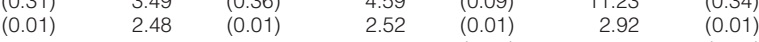

$\begin{array}{rrrr}-6.36 & (0.01) & -2.69 & (0.09) \\ 7.68 & (0.07) & 11.18 & (0.08)\end{array}$

$12.34 \quad(0.31)$

$\begin{array}{ll}1.45 & (1.30)\end{array}$

$\begin{array}{rr}1.45 & (1.30) \\ -0.75 & (0.43)\end{array}$

$\begin{array}{ll}-2.98 & (-0.03) \\ -0.44 & (0.01)\end{array}$

Yes

$\begin{array}{cc}\text { Yes } & \text { Yes } \\ \text { Yes } & \text { Yes } \\ \text { SIC2 } & \text { SIC2 } \\ 0.208 & 0.208 \\ 52,679 & 52,679\end{array}$


on average have a ratio of cash to total assets of $16.48 \%$, while firms with large shareholder bases (positive ExShBase) maintain average cash holdings of $12.76 \%$ of total assets (or $29.95 \%$ less). The difference is statistically significant at the $1 \%$ level. The effect is similar in economic magnitude and statistically significant when we consider median cash holdings.

Panel B of Table 5 displays our regression analysis. Specifications 1 and 2 are cross-sectional Fama-MacBeth (1973) regression, while the other specifications are pooled panel regressions. The coefficient of ExShBase is negative and statistically significant in all specifications, indicating that the shareholder base is negatively related to cash holdings. Inspecting specification 4 that includes a squared term, ExShBase ${ }^{2}$, we see that going from the 25th to the 75th percentile in terms of ExShBase decreases Cash by $0.75 \%$, which represents $5.26 \%$ of the unconditional mean. However, going from the 25th to the 50th percentile of ExShBase decreases Cash by $0.45 \%$, and going from the 50th to the 75th percentile of ExShBase only decreases Cash by $0.30 \%$. Therefore, just as with Total Payout, the relation between the ExShBase and Cash is nonlinear. The relation is stronger for firms with small shareholder bases. The economic magnitude of the shareholder base is similar across all of our specifications.

The relative impact of the shareholder base on Cash is economically significant. Considering specification 3, the impact of ExShBase is roughly 35\% the impact of Market Capitalization and 19\% the impact of BM. Specification 6 illustrates that the impact of the shareholder base on Cash is $84 \%$ of G-index, but 2.7 times larger than the impact of Board Size.

Like in the payout case, we investigate whether the need for external financing attenuates the impact of the shareholder base. Specifications 2 and 5 document that the slope coefficient is significantly lower for those firms that have a need for external financing, indicating that for firms that have no surplus earnings to retain, the effect of the shareholder base on cash is weakened.

Concerning the control variables, we find that larger firms have lower Cash ratios. Since large firms consist of more projects that have less than perfectly correlated cash needs, it makes sense that larger firms maintain smaller cash-to-asset levels. Likewise, value firms (high $B M$ ratio) have lower cash holdings. The lower cash holdings of large firms and firms with high $B M$ ratios has also been documented by Opler et al. (1999) and Dittmar, Mahrt-Smith, and Servaes (2003). Additionally, firms with high levels of Capex have lower Cash ratios. Variables that are related to the amount of cash that is disgorged to investors, such as Institutional Ownership and DE level, are also associated with lower cash holdings. Finally, firms that are more financially constrained according to the Whited-Wu index have larger cash holdings.

\section{Decimalization, the Shareholder Base, and Payout}

So far, we document that there is a relation between the shareholder base, payout, and cash. However, this does not establish that having a large shareholder base leads to higher payout levels and lower cash retention. It could equally well be that the firm's payout and cash policies attract a larger shareholder base. 
To establish a causal link, we need an exogenous shock that affects the shareholder base but does not alter the firm's operations and thereby has no direct effect on payout policy or cash holdings. The introduction of decimal quotes on the NYSE, NASDAQ, and AMEX in the middle of 2000 to the end of April 2001 significantly lowered the transaction costs associated with trading stocks and thereby increased investor demand and therefore also the size of the shareholder base. ${ }^{24}$ This effectively alters the demand for the firm's stock without directly affecting the firm's investment opportunity set. Despite the market collapsing in early to mid 2001, the average firm's shareholder base increased by $2.56 \%$ between the end of 1999 and the end of 2001. Fang, Noe, and Tice (2009) use decimalization to establish a causal link between liquidity and firm performance. ${ }^{25}$ In an earlier contribution, Amihud et al. (1999) consider a very similar experiment. They examine the effect of a reduction in the minimum trading lot in Japan and find that this institutional change is associated with an increase in the shareholder base, liquidity, and stock price.

Like Fang et al. (2009), we consider the change in our dependent variables (Total Payout and Cash) 1 year prior to the event to 1 year after the event. We choose this event window since each market shifted some stocks to decimal trading at earlier dates. ${ }^{26}$ Our main independent variable is the change in the shareholder base. As a control variable we include $\Delta$ Effective Relative Spread to capture the impact of changes in liquidity on payout and cash holdings. ${ }^{27}$ Additionally, in case decimalization affected the relative incentives of retail investors and institutional investors to hold shares, we have included the change in Institutional Ownership (measured as the change in the fraction of outstanding equity held by institutional investors) as a control variable. The correlations between $\Delta \log$ \#Shareholders, $\Delta$ Institutional Ownership, and $\Delta$ Effective Relative Spread are all below $10 \%$ in absolute terms.

Panel A of Table 6 presents our results when we consider the change in Total Payout as the dependent variable. The main independent variable in specification 1 , the change in the log of the number of shareholders, is positively and statistically significantly (at the $1 \%$ level) related to $\Delta$ Total Payout. In terms of economic significance, a 1-standard-deviation larger change in the log of number of shareholders leads to a $0.25 \%$ larger increase in $\Delta$ Total Payout. This should be compared to mean change in Total Payout of $-0.89 \%$ over our observation

\footnotetext{
${ }^{24}$ On Jan. 29, 2001, NYSE and AMEX switched to decimal quotes while NASDAQ switched on Apr. 9.

${ }^{25}$ Both Bessembinder (2003) and Furfine (2003) have documented that decimalization had a significant impact on transaction costs. They also find that the gain is restricted to those stocks that are actively traded.

${ }^{26}$ Bessembinder (2003) notes that roughly 150 stocks on NYSE were introduced at various dates to decimal trading prior to Jan. 29, 2001. Likewise, roughly 200 stocks on NASDAQ were shifted to decimal trading on 2 dates prior to Apr. 9.

${ }^{27}$ We use the Effective Relative Spread as opposed to Stock Liquidity, which we use in the rest of the paper, for two reasons. First, we want to make sure that our results are comparable to those of Fang et al. (2009). Second, Stock Liquidity requires the data from the previous year, which would mean having data for the numerator from after the event and data for the denominator from before the event. Nonetheless, our results are not qualitatively altered depending on our choice of liquidity definition.We are grateful to Shane Corwin for sharing with us data on Relative Spreads estimated from TAQ.
} 


\section{TABLE 6}

\section{Decimalization, Shareholder Base, and Payout}

In Table 6, we relate changes in the shareholder base to changes in total payout and cash holdings around the introduction of decimal trading quotes on NYSE, AMEX, and NASDAQ in 2000/2001 (decimalization). Following Fang et al. (2009), changes in all variables are calculated as the difference between the value of the variable at the end of 2001 and at the end of 1999 . Panel A reports the effect of changes in the shareholder base on changes in total payout. We consider both the full sample of companies as well as only the companies that had a positive total payout in 1999. Panel B investigates the impact of changes in the shareholder base around decimalization on changes in cash holdings. Relative effective spread is the trade-weighted average of bid-ask spread adjusted by the midpoint of bid-ask range. Total assets is the book value of company total assets (Compustat data 6). Residual volatility is 4-factor-adjusted volatility of company stock returns estimated over a 1-year window from daily data and expressed in yearly terms. All other variables are described in the Appendix. We utilize industry fixed effects. Standard errors are clustered at industry level. All estimates are multiplied by $100 . p$-values are in parentheses.

Panel A. Change in Shareholder Base and Change in Total Payout

Full Sample

\begin{tabular}{|c|c|c|c|}
\hline \multicolumn{2}{|c|}{1} & \multicolumn{2}{|c|}{2} \\
\hline Estimate & $p$-Value & Estimate & $p$-Value \\
\hline 0.26 & $(0.00)$ & $\begin{array}{l}0.38 \\
0.21\end{array}$ & $\begin{array}{l}(0.00) \\
(0.00)\end{array}$ \\
\hline
\end{tabular}

$\times$ Price $\$ 5-\$ 10$
$\times$ Price $>\$ 10$

$\triangle$ ExShBase

$\times$ Price $\$ 5-\$ 10$

$\times$ Price $>\$ 10$

$\Delta$ Institut. ownership

$\Delta$ Relative eff. spread

$\Delta \log$ (Total assets)

$\Delta$ Residual volatility

$\triangle$ Past year return

Industry fixed effects

Clustering

Adj. $R^{2}$

$(0.00)$

0.15
-5.60
-0.75

-5.60
-0.75

-7.95
-0.52

Yes

SIC2
2,724

2,724
0.023
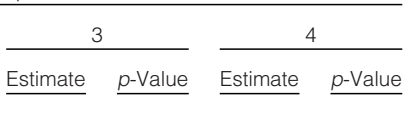

Estimate $\underline{p \text {-Value }}$

$$
0.54 \quad(0.00)
$$

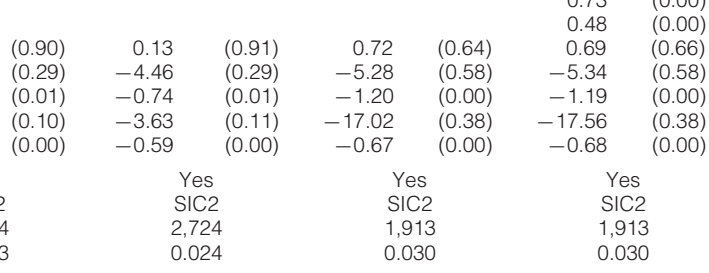

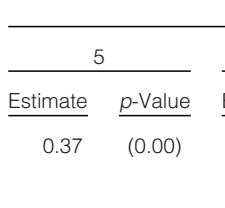

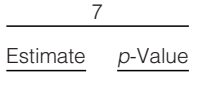

$\frac{8}{\underline{\text { Estimate }} \quad \underline{p \text {-Value }}}$

$0.60 \quad(0.06)$

$0.36 \quad(0.02)$
0

\begin{tabular}{ccrr}
0.66 & $(0.01)$ & 0.82 & $(0.01)$ \\
& & 0.62 & $(0.03)$ \\
-1.13 & $(0.53)$ & -1.13 & $(0.52)$ \\
-10.43 & $(0.26)$ & -10.48 & $(0.25)$ \\
-2.91 & $(0.00)$ & -2.92 & $(0.00)$ \\
-24.67 & $(0.32)$ & -24.77 & $(0.31)$ \\
-0.75 & $(0.00)$ & -0.76 & $(0.00)$ \\
Yes & \multicolumn{3}{c}{ Yes } \\
SIC2 & \multicolumn{3}{c}{ SIC2 } \\
1,779 & \multicolumn{3}{c}{1,396} \\
0.055 & \multicolumn{3}{c}{0.055}
\end{tabular}

(continued on next page) 
TABLE 6 (continued)

Decimalization, Shareholder Base, and Payout

Panel B. Change in Shareholder Base and Change in Cash Holdings

\begin{tabular}{|c|c|c|c|c|c|c|c|c|}
\hline \multirow[b]{2}{*}{ Change in Cash } & \multicolumn{2}{|c|}{1} & \multicolumn{2}{|c|}{2} & \multicolumn{2}{|c|}{3} & \multicolumn{2}{|c|}{4} \\
\hline & Estimate & $p$-Value & Estimate & $p$-Value & Estimate & $p$-Value & Estimate & $p$-Value \\
\hline $\begin{array}{c}\Delta \log (\# \text { Shareholders }) \\
\times \text { Price } \$ 5-\$ 10 \\
\times \text { Price }>10\end{array}$ & -0.89 & $(0.06)$ & $\begin{array}{l}-1.11 \\
-0.54\end{array}$ & $\begin{array}{l}(0.04) \\
(0.29)\end{array}$ & & & & \\
\hline $\begin{array}{l}\Delta \text { ExShBase } \\
\times \text { Price } \$ 5-\$ 10 \\
\times \text { Price }>\$ 10\end{array}$ & & & & & -1.05 & $(0.03)$ & $\begin{array}{l}-1.60 \\
-0.85\end{array}$ & $\begin{array}{l}(0.05) \\
(0.04)\end{array}$ \\
\hline$\Delta$ Institut. ownership & 10.98 & $(0.00)$ & 10.88 & $(0.00)$ & 13.08 & $(0.01)$ & 13.18 & $(0.01)$ \\
\hline$\Delta$ Relative eff. spread & 22.00 & $(0.06)$ & 22.49 & $(0.06)$ & 27.47 & $(0.34)$ & 27.48 & $(0.34)$ \\
\hline$\Delta \log$ (Total assets) & 10.77 & $(0.00)$ & 10.80 & $(0.00)$ & 11.12 & $(0.00)$ & 11.10 & $(0.00)$ \\
\hline$\Delta$ Residual volatility & -49.06 & $(0.06)$ & -49.63 & $(0.06)$ & -74.45 & $(0.37)$ & -72.88 & $(0.38)$ \\
\hline$\Delta$ Past year return & 1.64 & $(0.07)$ & 1.64 & $(0.05)$ & 1.00 & $(0.29)$ & 1.01 & $(0.29)$ \\
\hline Industry fixed effects & \multirow{2}{*}{\multicolumn{2}{|c|}{ Yes }} & \multicolumn{2}{|c|}{ Yes } & \multicolumn{2}{|c|}{ Yes } & \multicolumn{2}{|c|}{ Yes } \\
\hline Clustering & & & \multirow{2}{*}{\multicolumn{2}{|c|}{2,724}} & & & \multirow{2}{*}{\multicolumn{2}{|c|}{1913}} \\
\hline N & \multicolumn{2}{|c|}{2,724} & & & \multicolumn{2}{|c|}{1,913} & & \\
\hline Adj. $R^{2}$ & \multicolumn{2}{|c|}{0.1284} & \multicolumn{2}{|c|}{0.1281} & \multicolumn{2}{|c|}{0.1197} & \multicolumn{2}{|c|}{0.1194} \\
\hline
\end{tabular}

period. Specification 3 is identical to specification 1 except that we consider the $\triangle E x$ ShBase as the main independent variable. A 1-standard-deviation increase in $\triangle E x S h B a s e$ leads to an increase in $\Delta$ Total Payout of $0.40 \%$, and the effect is statistically significant at the $1 \%$ level.

We consider the same control variables as Fang et al. (2009) with the exception of the Standard \& Poor's (S\&P) 500 dummy variable that is insignificant in all of their specifications. Interestingly, the change in institutional ownership is never statistically significantly related to the change in Total Payout and the sign of the coefficient changes depending on whether we consider only firms with positive payout.

An equal decline in transaction costs across stocks implies a larger relative impact on stocks with low prices. Therefore it is likely that decimalization was a larger event for low price stocks. To investigate this conjecture we introduce 2 dummy variables: Low Price (High Price), which takes the value 1 if the price is between $\$ 5$ and $\$ 10$ (above $\$ 10$ ), and 0 otherwise. In our sample, 36.72\% of stocks were in the $\$ 5-\$ 10$ price range at the end of 1999. In specifications 2 and 4 we interact our measure of the shareholder base with dummy variables for the stock price level to examine whether the strength of the relation differs across stock price levels. As expected, in both specifications the economic effect is substantially larger for low price stocks.

To make sure that our results are not in some way influenced by nonpaying firms, we consider only firms that have positive payout levels in the beginning of 1999 in specifications 5-8. Specifications 5 and 6 have as main independent variable the change in the log of the number of shareholders, while specifications 7 and 8 consider $\Delta E x$ ShBase. The significance levels and economic impact are very similar to specifications $1-4$.

In Panel B of Table 6 we consider $\triangle$ Cash as dependent variable. Like in Panel A, we consider the change in the log of the number of shareholders in specifications 1 and 2, while specifications 3 and 4 use $\Delta E x S h B a s e$ as the main independent variable. In both specifications our proxy for the change in the share- 
holder base is negatively related to the change in cash holdings ( $\Delta$ Cash), and the relation is statistically significant at the $1 \%$ level. In specification 1 , a 1-standard-deviation increase in the change in the number of shareholders results in a reduction of cash holdings of $1.61 \%$. The corresponding impact in specification 3 of $\triangle E x$ ShBase on the change in cash holdings is a reduction of $3.26 \%$. These numbers should be compared to the unconditional mean change in cash holdings of $-2.25 \%$. Specifications 2 and 4 interact our dummy variables Low Price and High Price with our measures of the shareholder base. Similarly to when we considered payout, the relation between changes in the shareholder base and $\Delta$ Cash is significantly stronger for low price stocks for which decimalization was a larger event. Additionally, we find that firms that experience positive changes in Institutional Ownership, Total Assets, and Past Year Return also have positive changes in cash levels. In both panels of Table 6, we include industry fixed effects and cluster standard errors on the industry level.

The results of these panels indicate that when there is an exogenous drop in the transaction costs associated with trading in stocks, firms experience an increase in the shareholder base. This relation has been documented by Amihud et al. (1999), who find that reducing trading costs results in an increase in the shareholder base, liquidity, and stock price. We build on this by showing that there is a relation between the increase in the shareholder base and how payout and cash holdings change. A larger change in the shareholder base results in a larger positive change in payout and a smaller change in cash holdings. Both of these results are indicative of the cost of external financing being related to the size of the shareholder base.

Although no event is a perfect natural experiment, we believe that decimalization has a number of advantages over other events such as the Jobs and Growth Tax Relief Reconciliation Act of 2003 and state-level tax changes. By altering the relative tax treatment of repurchases and dividend, the Jobs and Growth Tax Relief Reconciliation Act of 2003 altered the incentives for the 2 payout methods. Therefore, this event has implications for clientele effects. State-level tax changes are often endogenous to the performance of firms within the state. So, an increase in state-level taxes might be motivated by low tax revenues from state firms, which then coincide with low firm payouts. In this setting, it would be hard to argue that the lower payout is driven by a reduction in the shareholder base due to an increase in taxes rather than poor firm performance. The advantage with decimalization as an event is that it is most likely unrelated to firm performance.

\section{Repurchases and the Shareholder Base}

In this section we investigate Hypothesis 2: whether a repurchase reduces the size of the shareholder base. To argue that maintaining the size of the shareholder base is an important consideration when choosing the method of payout, we need to verify that undertaking a share repurchase and paying special dividends affects the shareholder base differently. In particular, for special dividends to have an advantage over repurchases we should observe that the latter reduces the shareholder base (and thus increases the cost of external financing), while the former 
does not. Therefore, we examine the effect of repurchases and special dividends on the size of the shareholder base.

Table 7 presents the results from pooled panel regressions. Our dependent variable is the change in the logarithm of the number of common shareholders ( $\triangle$ ShBase) in year $t$ (and $t+1$ ), where $t$ is the year when the special distribution is made. We present results in terms of changes in the number of common shareholders to facilitate interpretation, but the results in terms of changes in ExShBase are qualitatively equivalent. ${ }^{28}$ Our main variables of interest are Share Repurchase and Special Dividend. Share Repurchase is a dummy variable that takes the value of 1 if the firm has repurchased at least $1 \%$ of its outstanding stock in year $t$. Special Dividend is a dummy variable that takes the value of 1 if the firm undertakes a special dividend in year $t$. We find that undertaking a repurchase leads to a decline in the shareholder base over years $t$ and $t+1$. Undertaking a repurchase in year $t$ leads to a reduction in the shareholder base in year $t$ of between $1.26 \%$ and $2.41 \%$. This reduction continues in year $t+1$, so over 2 years $(t$ and $t+1)$

\section{TABLE 7}

The Effect of Share Repurchases and Special Dividends on Shareholder Base

In Table 7, we present the results of the effect of share repurchases and special dividends on the shareholder base in the year when the special distribution is undertaken and in the subsequent year. The change in shareholder base in year is calculated as the difference in the logarithm of the number of common shareholders of record at the end of year $t$ and year $t-1$. The dependent variable is the change in shareholder base at year $t(t+1)$, where year $t$ is a year when a special distribution is made. All variables are described in the Appendix. All estimates are multiplied by 100 . $p$-values are in parentheses.

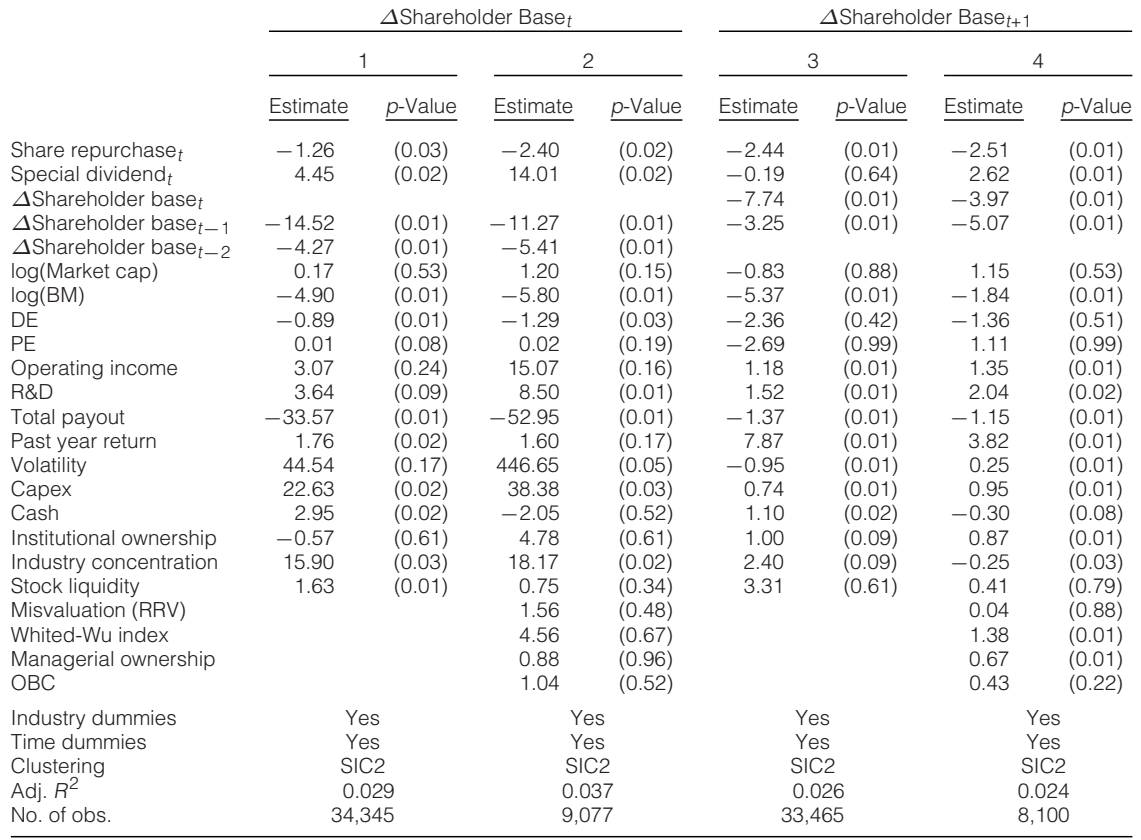

\footnotetext{
${ }^{28}$ The correlation between $\triangle E x$ ShBase and changes in log number of shareholders is $86.9 \%$.
} 
the shareholder base is reduced by between $3.70 \%$ and $4.91 \% .^{29}$ At the same time, paying a special dividend leads to an increase in the shareholder base. This increase in the shareholder base could be due to the attention that is associated with a special dividend. These results demonstrate that repurchases and special dividends have substantial and asymmetric effects on the shareholder base. If the shareholder base is valuable, then there is a clear disadvantage to using a repurchase as the distribution method.

One potential concern is that firms may issue equity in the future to counter the negative impact of the repurchase on the shareholder base. In unreported results we find that repurchasing firms are less likely to undertake a seasoned equity offering at any point over the next 3 years. Therefore, if anything, the difference in shareholder base between repurchasing and nonrepurchasing firms is widened over the following 3 years.

Open market repurchase programs often continue for several years, so a firm that repurchases in year $t$ is likely to have repurchased in year $t-1$. To control for this, we include the change in the shareholder base over the previous year $\left(\triangle\right.$ ShBase $\left._{t-1}\right)$ and the year before that $\left(\Delta\right.$ ShBase $\left._{t-2}\right)$ in our specifications. It turns out that there is a negative and significant relation between current changes and previous changes, implying that there is a certain amount of mean reversion in the shareholder base. However, the amount of mean reversion present is limited, since Table 3 illustrates that having a small or large shareholder base is a fairly persistent characteristic.

\section{E. The Shareholder Base and the Choice of Payout Method}

In this section we investigate Hypothesis 3: whether the size of the shareholder base matters for the choice of payout method. If maintaining a broad shareholder base is valuable to the firm, then the choice of distribution method is important. A repurchase reduces the size of the shareholder base and is therefore costly. As a result, firms with particularly small shareholder bases should be more reluctant to reduce the size of the shareholder base through a repurchase. On the other hand, a special dividend does not reduce the size of the shareholder base. Therefore, we expect that firms that have particularly small shareholder bases should be more likely to undertake special dividends, while firms with large shareholder bases should favor repurchases that are more tax efficient.

In Panel A of Table 8, we examine the univariate relation between the shareholder base and the decision to undertake a repurchase and pay special dividends. We split firms into 2 groups depending on whether they have an ExShBase that is below or above $0 .^{30}$

We find that firms with large shareholder bases are $7.5 \%$ more likely to undertake a repurchase than small shareholder base firms. The difference is significant at the $1 \%$ level. Additionally, large shareholder base firms repurchase $20.5 \%$ more than small shareholder base firms.

\footnotetext{
${ }^{29}$ In unreported results, we find that there is no relation between special distributions and the change in the shareholder base in year $t+2$.

${ }^{30}$ These results are qualitatively unaltered if we use the median level of the ExShBase as breakpoint.
} 
The probability that a firm with a large (small) ExShBase undertakes a special dividend is $1.40 \%(2.02 \%)$. The $0.62 \%$ difference between firms with positive and negative ExShBase is statistically significant. So, firms with large shareholder bases are more likely to undertake a repurchase and less likely to undertake a special dividend than firms with small shareholder bases.

The decision to undertake a repurchase or a special dividend can be seen as two sequential decisions. First, the firm decides whether to make a special distribution to shareholders. Second, the firm chooses the method of distribution. Hypothesis 3 suggests that given a special distribution, firms with a small shareholder base should be more likely to undertake a special dividend. In Panels B and $\mathrm{C}$ of Table 8 we relate the shareholder base to the method of payout while

\section{TABLE 8}

\section{Shareholder Base and the Choice of Payout Method}

In Table 8, we relate the excess shareholder base to the likelihood of paying a special dividend and undertaking a repurchase. Panel A presents univariate results on the relation between the excess shareholder base and the decision to pay a special dividend and repurchase stock (likelihood and size) in the subsequent year. Panel B presents results of a probit analysis of the relation between the excess shareholder base and the likelihood of undertaking a special distribution (share repurchase or special dividend). The dependent variable is a dummy variable that takes the value of 1 if the company makes a special distribution (special dividend or repurchase) in the following year, and 0 otherwise. Panel $\mathrm{C}$ presents the results of a probit analysis relating the excess shareholder base to the method of a special distribution. The dependent variable is a dummy variable that takes the value of 1 if the special distribution is a repurchase, 0 if it is a special dividend. We control for selectivity utilizing Heckman's lambda from the selection regression reported in Panel B. All regressions control for time and industry fixed effects with standard errors clustered at industry level. Residuals from the regression reported in Table 2 are used as our measure of the shareholder base. All variables are described in the Appendix. Marginal effects (ME) for all variables are multiplied by 100. $p$-values are in parentheses.

Panel A. Univariate Analysis

\begin{tabular}{|c|c|c|c|c|c|c|c|c|c|c|}
\hline \multirow[b]{2}{*}{ Excess Shareholder Base } & \multirow[b]{2}{*}{$N$} & \multicolumn{3}{|c|}{$\begin{array}{l}\text { Likelihood of } \\
\text { Special Dividend }\end{array}$} & \multicolumn{3}{|c|}{$\begin{array}{l}\text { Likelihood of } \\
\text { Repurchase }\end{array}$} & \multicolumn{3}{|c|}{$\begin{array}{c}\text { Size of } \\
\text { Repurchase }\end{array}$} \\
\hline & & Mean & t-Stat. & Prob. & Mean & $t$-Stat. & Prob. & Mean & $t$-Stat. & Prob. \\
\hline $\begin{array}{l}\text { High (positive) } \\
\text { Low (negative) }\end{array}$ & $\begin{array}{l}28,065 \\
27,939\end{array}$ & $\begin{array}{l}1.40 \% \\
2.02 \%\end{array}$ & 5.61 & 0.01 & $\begin{array}{l}23.48 \% \\
21.84 \%\end{array}$ & 4.63 & 0.01 & $\begin{array}{l}1.41 \% \\
1.17 \%\end{array}$ & 6.75 & 0.01 \\
\hline
\end{tabular}

Panel B. Shareholder Base and the Decision to Undertake a Special Distribution

\begin{tabular}{|c|c|c|c|}
\hline \multirow[b]{2}{*}{ Special Distribution Dummy } & \multicolumn{3}{|c|}{1} \\
\hline & Estimate & $p$-Value & $\mathrm{ME}$ \\
\hline ExShBase & 0.03 & $(0.01)$ & 0.84 \\
\hline $\log ($ Market cap) & 0.09 & $(0.01)$ & 2.70 \\
\hline $\log (B M)$ & 0.17 & $(0.01)$ & 4.93 \\
\hline $\mathrm{DE}$ & -0.02 & $(0.32)$ & -0.51 \\
\hline $\mathrm{PE}$ & -0.00 & $(0.06)$ & -0.01 \\
\hline Operating income & 2.64 & $(0.01)$ & 76.02 \\
\hline$R \& D$ & 0.13 & $(0.19)$ & 3.82 \\
\hline Dividend-to-earnings & -0.16 & $(0.10)$ & -4.62 \\
\hline Repurchase-to-earnings & 0.15 & $(0.01)$ & 4.36 \\
\hline Past year return & -0.13 & $(0.01)$ & -3.61 \\
\hline Volatility & -14.72 & $(0.01)$ & -424.36 \\
\hline Capex & -1.83 & $(0.01)$ & -52.86 \\
\hline Institutional ownership & 0.29 & $(0.01)$ & 8.26 \\
\hline Industry concentration & 0.13 & $(0.25)$ & 3.80 \\
\hline Stock liquidity & -0.05 & $(0.01)$ & -1.45 \\
\hline Misvaluation (RRV) & & & \\
\hline Whited-Wu index & & & \\
\hline $\log ($ Firm age) & 0.07 & $(0.01)$ & 2.11 \\
\hline Industry dummies & & Yes & \\
\hline Time dummies & & Yes & \\
\hline Clustering & & $\mathrm{SIC} 2$ & \\
\hline Adj. $R^{2}$ & & 0.101 & \\
\hline$N$ & & 52,526 & \\
\hline
\end{tabular}

\begin{tabular}{|c|c|c|}
\hline Estimate & $p$-Value & ME \\
\hline 0.03 & $(0.01)$ & 0.76 \\
\hline 0.07 & $(0.01)$ & 2.02 \\
\hline 0.04 & (0.04) & 0.99 \\
\hline-0.01 & $(0.40)$ & -0.40 \\
\hline-0.00 & $(0.11)$ & -0.01 \\
\hline 2.70 & $(0.01)$ & 76.30 \\
\hline 0.17 & $(0.01)$ & 4.76 \\
\hline-0.15 & $(0.01)$ & -4.35 \\
\hline 0.15 & $(0.01)$ & 4.22 \\
\hline-0.15 & $(0.01)$ & -4.25 \\
\hline-21.28 & $(0.01)$ & -601.71 \\
\hline-1.98 & $(0.01)$ & -56.11 \\
\hline 0.24 & $(0.01)$ & 6.68 \\
\hline 0.17 & $(0.29)$ & 4.77 \\
\hline-0.04 & $(0.01)$ & -1.26 \\
\hline-0.39 & $(0.04)$ & -10.99 \\
\hline-0.49 & $(0.01)$ & -13.94 \\
\hline \multirow[t]{7}{*}{0.08} & $(0.01)$ & 2.38 \\
\hline & \multicolumn{2}{|l|}{ Yes } \\
\hline & \multicolumn{2}{|l|}{ Yes } \\
\hline & \multicolumn{2}{|l|}{$\mathrm{SIC} 2$} \\
\hline & \multicolumn{2}{|l|}{0.112} \\
\hline & \multicolumn{2}{|l|}{38,450} \\
\hline & continued & \\
\hline
\end{tabular}


TABLE 8 (continued)

Shareholder Base and the Choice of Payout Method

Panel C. Shareholder Base and the Choice of Special Distribution (Share Repurchase vs. Special Dividend)

\begin{tabular}{|c|c|c|c|c|c|c|c|c|c|}
\hline \multirow[b]{2}{*}{ Share Repurchase Dummy } & \multicolumn{3}{|c|}{1} & \multicolumn{3}{|c|}{2} & \multicolumn{3}{|c|}{3} \\
\hline & Estimate & $p$-Value & $\mathrm{ME}$ & Estimate & $p$-Value & $\mathrm{ME}$ & Estimate & $p$-Value & $\mathrm{ME}$ \\
\hline ExShBase & 0.12 & $(0.02)$ & 0.59 & 0.09 & $(0.09)$ & 0.39 & 0.13 & $(0.10)$ & 0.07 \\
\hline log(Market cap) & 0.13 & $(0.10)$ & 0.66 & 0.03 & $(0.82)$ & 0.11 & 0.19 & $(0.06)$ & 0.10 \\
\hline $\log (B M)$ & 0.09 & $(0.55)$ & 0.44 & -0.14 & $(0.44)$ & -0.56 & 0.00 & $(1.00)$ & 0.00 \\
\hline $\mathrm{DE}$ & 0.05 & (0.31) & 0.27 & 0.09 & $(0.24)$ & 0.33 & 0.28 & $(0.18)$ & 0.15 \\
\hline $\mathrm{PE}$ & 0.00 & $(0.37)$ & -0.01 & 0.00 & $(0.26)$ & 0.00 & 0.00 & $(0.03)$ & 0.00 \\
\hline Operating income & 0.66 & $(0.77)$ & 3.26 & -2.85 & $(0.16)$ & -11.32 & 0.21 & $(0.91)$ & 0.12 \\
\hline$R \& D$ & 5.68 & $(0.01)$ & 28.17 & 7.43 & $(0.01)$ & 29.75 & 2.38 & $(0.28)$ & 1.33 \\
\hline Dividend-to-earnings & -0.43 & $(0.01)$ & -2.12 & -0.27 & $(0.03)$ & -1.07 & -0.22 & $(0.01)$ & -0.93 \\
\hline Repurchase-to-earnings & 0.32 & $(0.01)$ & 1.59 & 0.20 & $(0.10)$ & 0.79 & 0.12 & $(0.17)$ & 0.47 \\
\hline Past year return & -0.53 & $(0.01)$ & -2.61 & -0.37 & $(0.01)$ & -1.49 & -0.31 & $(0.17)$ & -0.17 \\
\hline Volatility & 7.72 & (0.39) & 38.30 & 30.22 & $(0.06)$ & 119.82 & 18.75 & $(0.75)$ & 10.46 \\
\hline Capex & -0.60 & $(0.75)$ & -3.00 & 1.53 & $(0.34)$ & 6.07 & -0.20 & $(0.91)$ & -0.11 \\
\hline Institutional ownership & 0.95 & $(0.01)$ & 4.72 & 0.55 & (0.03) & 2.17 & 1.11 & $(0.07)$ & 0.62 \\
\hline Industry concentration & 0.50 & $(0.40)$ & 2.48 & 0.62 & $(0.20)$ & 2.46 & 3.06 & $(0.13)$ & 1.71 \\
\hline Stock liquidity & 0.03 & $(0.49)$ & 0.16 & 0.08 & $(0.16)$ & 0.31 & 0.26 & $(0.27)$ & 0.14 \\
\hline Misvaluation (RRV) & & & & 0.02 & $(0.83)$ & 0.09 & -0.78 & $(0.13)$ & -0.44 \\
\hline Whited-Wu index & & & & 0.02 & $(0.98)$ & 0.06 & 0.67 & $(0.36)$ & 0.37 \\
\hline Managerial ownership & & & & & & & -0.38 & $(0.85)$ & -0.21 \\
\hline OBC & & & & & & & 1.29 & $(0.00)$ & 0.72 \\
\hline G-index & & & & & & & 0.07 & $(0.01)$ & 0.04 \\
\hline Lambda & 0.71 & $(0.70)$ & 3.51 & -0.90 & $(0.38)$ & -3.55 & -0.52 & $(0.48)$ & -2.62 \\
\hline Industry dummies & & Yes & & & Yes & & & Yes & \\
\hline Time dummies & & Yes & & & Yes & & & Yes & \\
\hline Clustering & & $\mathrm{SIC} 2$ & & & SIC2 & & & SIC2 & \\
\hline Adj. $R^{2}$ & & 0.195 & & & 0.235 & & & 0.296 & \\
\hline$N$ & & 12,336 & & & 8,947 & & & 3,330 & \\
\hline
\end{tabular}

conditioning on the decision to make a special distribution to shareholders. To do this, we employ a 2-stage probit procedure, where the dependent variable in the 1st stage is a dummy variable that takes the value of 1 if the firm undertakes a special distribution (repurchase or special dividend), and 0 otherwise. In the 2 nd stage, the dependent variable is a dummy variable that takes the value of 1 if the firm undertakes a repurchase and 0 if the firm undertakes a special dividend.

Examining the 1st-stage regressions in Panel B of Table 8, we find firms with larger shareholder bases are more likely to make special distributions, which is consistent with our earlier findings for total payout. In particular, going from 25 th to 75th percentile of ExShBase increases the likelihood of a special distribution by $1.32 \%$, or $6.09 \%$ relative to the unconditional mean. Additionally, we find that larger firms, value firms, firms with greater operating income, and firms with larger amounts of payout in the previous period are more likely to undertake a special distribution. Firms with larger institutional ownership and low dividend payout are also more likely to undertake a one-time distribution.

In the 2nd stage we consider the method of payout while conditioning on the decision to undertake a special distribution. We find that firms with smaller shareholder bases favor paying special dividends over undertaking repurchases. In particular, a decrease in excess shareholder base from 75 th to 25 th percentile increases the likelihood that a special distribution is a special dividend by $1.08 \%$ (or $13.97 \%$ relative to the unconditional mean). The 2 nd-stage regression also indicates that when controlling for the decision to make a special distribution, 
firms with high levels of dividend payout and good past performance are less likely to use a repurchase as a payout method. The results of this section indicate that firms with limited shareholder bases are reluctant to use repurchase as a method of payout.

\section{Robustness}

There is an extensive literature on the relation between the composition of the shareholder base and payout policy. For example, institutions may prefer to hold stocks with a particular payout policy for tax reasons. This would imply causality from the payout policy to the ownership structure. However, the causality could also be the reverse: Institutions prefer a particular payout policy, and they encourage the firm to follow this policy. Two recent contributions to this literature are Graham and Kumar (2006) and Grinstein and Michaely (2005), which consider clientele effects due to retail investors and institutional ownership, respectively. This literature raises two relevant issues for our paper. First, is it possible that serial correlation in payout in conjunction with reverse causality could explain our results? The story would be that payout policy determines the size of the shareholder base, and current levels of payout are determined by past levels of payout. To explore this issue, in this section we examine the relation between our variables of interest in a series of vector autoregressions. Second, is our variable of interest, ExShBase, related to the ownership composition of the firm? To address this, we conduct multivariate sorts to verify that the relation between ExShBase and Total Payout and Cash holds for stocks with different investor composition and other characteristics that different clienteles might show preference over.

To examine whether past levels of payout determine both current levels of payout and the size of the shareholder base, we estimate the following set of vector autoregressions (e.g., Grinstein and Michaely (2005)):

$$
\begin{aligned}
\text { Payout }_{i, t+1} & =c_{0}+c_{1} \text { Payout }_{i, t}+d_{1} \text { ExShBase }_{i, t}+\phi \mathbf{W}_{t}+\varepsilon_{i, t+1}, \\
\text { Cash }_{i, t+1} & =a_{0}+a_{1} \text { Cash }_{i, t}+b_{1} \text { ExShBase }_{i, t}+\boldsymbol{\beta} \mathbf{W}_{t}+\nu_{i, t+1}, \\
\text { ExShBase }_{i, t+1} & =k_{0}+k_{1} \text { ExShBase }_{i, t}+l_{1} \text { Cash }_{i, t}+z_{1} \text { Payout }+\gamma \mathbf{W}_{t}+\eta_{i, t+1},
\end{aligned}
$$

where Payout, Cash, and ExShBase are defined as before; $\mathbf{W}_{t}$ is a vector of control variables; and the corresponding coefficients are given by $\boldsymbol{\phi}, \boldsymbol{\beta}$, and $\boldsymbol{\gamma}$ for the respective equation. ${ }^{31}$ As always, we include industry and time dummy variables and cluster standard errors at the industry level.

The estimation results in Table 9 indicate that the ExShBase Granger causes Payout and Cash. However, it does not appear as if past levels of Cash and Payout Granger cause ExShBase. These results and the effect of decimalization (see Section IV.C) are supportive of the thesis that the shareholder base affects payout and cash holdings of firms.

\footnotetext{
${ }^{31}$ We use the Akaike information criterion to determine the optimal number of lags. We cannot reject the hypothesis that the optimal number of lags is 1 .
} 
TABLE 9

VAR

In Table 9, we report the results of panel vector autoregressive (VAR) regressions (with 1 lag). The dependent variables are measured at the end of next year. All other variables are measured at the end of current year. All variables are described in the Appendix. All estimates are multiplied by 100. p-values are in parentheses.

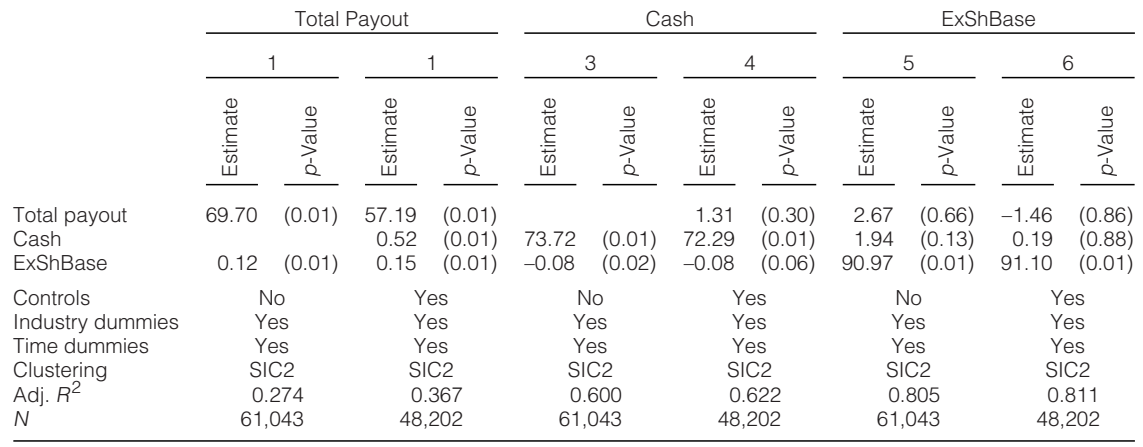

To illustrate that the relation between the shareholder base and payout is not driven by investor composition, we conduct multivariate sorts in Table 10. In Panel A of Table 10, we first sort companies into 5 size quintiles followed by 2 groups, by either Institutional Ownership (IO) or BM or Whited-Wu or Misvaluation. Following this, all stocks are split into 2 groups according to their ExShBase. This implies that we have 20 groups of stocks $(5 \times 2 \times 2)$. We report the difference in Total Payout between large shareholder base firms (greater than median ExShBase) and small shareholder base firms. From Hypothesis 1, we expect this difference to be positive. Examining the results for the 3-way sort on size, Institutional Ownership, and ExShBase, we find that in the majority of cases, large shareholder base firms have larger levels of Total Payout. It is comforting to observe that the exceptions to this relation are found among the smallest firms (size quintiles 1 and 2). The 3-way sorts on size, BM, and ExShBase, indicate that whether the stock is a value or glamour stock cannot explain the larger payout levels of large shareholder base firms. Similar conclusions can be drawn when examining the sorts on Whited-Wu and Misvaluation. The results remain economically and statistically significant when considering median payout levels, which indicates that outliers are not driving our results.

In Panel B of Table 10, we follow the same sorting procedure as in Panel A, but consider differences in Cash holdings between large and small shareholder base firms. Following Hypothesis 1, we expect the difference to be negative. Examining the results for Institutional Ownership, we find that in the majority of cases, large shareholder base firms have lower cash holdings (except for size quintiles 1 and 2, where the difference is not always significant). Overall, when examining the other variables that we sort on, we find strong support for the hypothesis that large shareholder base firms have lower cash holdings.

The evidence presented in Table 10 indicates that the differences in Total Payout and Cash between large and small shareholder base firms cannot be explained by differences in institutional ownership or other variables that might have clienteles. 
In Table 10, we examine the relation between excess shareholder base and total payout and cash holdings for different size, value, institutional ownership, financial constraints (Whited-Wu (WW) (2006)), and misvaluation groups. At the end of previous year, companies are sorted in $20(5 \times 2 \times 2)$ groups based on size, book-to-market (BM)/institutional ownership (IO)/WW index/misvaluation and excess shareholder base. In Panel A (Panel B) we report the difference in average and median total payout (cash holdings) between high and low excess shareholder base groups. Differences in total payout and cash holdings are multiplied by 100 , and $p$-values for 1 -sided $t$-test and Wilcoxon test are reported in parentheses.

\begin{tabular}{|c|c|c|c|c|c|c|c|c|c|c|c|c|c|c|c|c|}
\hline \multirow[b]{3}{*}{ Size } & \multicolumn{4}{|c|}{ BM } & \multicolumn{4}{|c|}{10} & \multicolumn{4}{|c|}{ WW } & \multicolumn{4}{|c|}{ Misvaluation } \\
\hline & \multicolumn{2}{|c|}{ Low } & \multicolumn{2}{|c|}{ High } & \multicolumn{2}{|c|}{ Low } & \multicolumn{2}{|c|}{ High } & \multicolumn{2}{|c|}{ Low } & \multicolumn{2}{|c|}{ High } & \multicolumn{2}{|c|}{ Low } & \multicolumn{2}{|c|}{ High } \\
\hline & Mean & Median & Mean & Median & Mean & Median & Mean & Median & Mean & Median & Mean & Median & Mean & Median & Mean & Median \\
\hline \multicolumn{17}{|c|}{ Panel A. Total Payout } \\
\hline Small & $\begin{array}{c}0.17 \\
(0.10)\end{array}$ & $\begin{array}{c}0.00 \\
(0.03)\end{array}$ & $\begin{array}{c}0.27 \\
(0.01)\end{array}$ & $\begin{array}{c}0.02 \\
(0.05)\end{array}$ & $\begin{array}{c}0.26 \\
(0.02)\end{array}$ & $\begin{array}{c}0.00 \\
(0.19)\end{array}$ & $\begin{array}{c}0.24 \\
(0.03)\end{array}$ & $\begin{array}{c}0.00 \\
(0.03)\end{array}$ & $\begin{array}{c}0.35 \\
(0.01)\end{array}$ & $\begin{array}{c}0.04 \\
(0.01)\end{array}$ & $\begin{array}{c}0.14 \\
(0.11)\end{array}$ & $\begin{array}{c}0.00 \\
(0.01)\end{array}$ & $\begin{array}{c}0.39 \\
(0.01)\end{array}$ & $\begin{array}{c}0.10 \\
(0.03)\end{array}$ & $\begin{array}{c}0.19 \\
(0.07)\end{array}$ & $\begin{array}{c}0.00 \\
(0.15)\end{array}$ \\
\hline 2 & $\begin{array}{c}0.56 \\
(0.01)\end{array}$ & $\begin{array}{c}0.00 \\
(0.01)\end{array}$ & $\begin{array}{c}0.32 \\
(0.01)\end{array}$ & $\begin{array}{c}0.06 \\
(0.01)\end{array}$ & $\begin{array}{c}0.84 \\
(0.01)\end{array}$ & $\begin{array}{c}0.12 \\
(0.01)\end{array}$ & $\begin{array}{c}0.06 \\
(0.55)\end{array}$ & $\begin{array}{c}-0.01 \\
(0.49)\end{array}$ & $\begin{array}{c}0.05 \\
(0.64)\end{array}$ & $\begin{array}{c}-0.23 \\
(0.04)\end{array}$ & $\begin{array}{c}0.26 \\
(0.01)\end{array}$ & $\begin{array}{c}0.00 \\
(0.02)\end{array}$ & $\begin{array}{c}0.44 \\
(0.01)\end{array}$ & $\begin{array}{c}0.02 \\
(0.14)\end{array}$ & $\begin{array}{c}0.58 \\
(0.01)\end{array}$ & $\begin{array}{c}0.03 \\
(0.01)\end{array}$ \\
\hline 3 & $\begin{array}{c}0.70 \\
(0.01)\end{array}$ & $\begin{array}{c}0.42 \\
(0.01)\end{array}$ & $\begin{array}{c}0.34 \\
(0.01)\end{array}$ & $\begin{array}{c}0.26 \\
(0.01)\end{array}$ & $\begin{array}{c}0.51 \\
(0.01)\end{array}$ & $\begin{array}{c}0.48 \\
(0.01)\end{array}$ & $\begin{array}{c}0.34 \\
(0.01)\end{array}$ & $\begin{array}{c}0.20 \\
(0.01)\end{array}$ & $\begin{array}{c}0.32 \\
(0.01)\end{array}$ & $\begin{array}{c}0.09 \\
(0.02)\end{array}$ & $\begin{array}{c}0.25 \\
(0.02)\end{array}$ & $\begin{array}{c}0.00 \\
(0.01)\end{array}$ & $\begin{array}{c}0.41 \\
(0.01)\end{array}$ & $\begin{array}{c}0.28 \\
(0.01)\end{array}$ & $\begin{array}{c}0.50 \\
(0.01)\end{array}$ & $\begin{array}{c}0.34 \\
(0.01)\end{array}$ \\
\hline 4 & $\begin{array}{c}0.91 \\
(0.01)\end{array}$ & $\begin{array}{c}0.85 \\
(0.01)\end{array}$ & $\begin{array}{c}0.47 \\
(0.01)\end{array}$ & $\begin{array}{c}0.56 \\
(0.01)\end{array}$ & $\begin{array}{c}0.79 \\
(0.01)\end{array}$ & $\begin{array}{c}0.82 \\
(0.01)\end{array}$ & $\begin{array}{c}0.34 \\
(0.01)\end{array}$ & $\begin{array}{c}0.32 \\
(0.01)\end{array}$ & $\begin{array}{c}0.70 \\
(0.01)\end{array}$ & $\begin{array}{c}0.39 \\
(0.01)\end{array}$ & $\begin{array}{c}0.49 \\
(0.01)\end{array}$ & $\begin{array}{c}0.26 \\
(0.01)\end{array}$ & $\begin{array}{c}0.48 \\
(0.01)\end{array}$ & $\begin{array}{c}0.67 \\
(0.01)\end{array}$ & $\begin{array}{c}0.63 \\
(0.01)\end{array}$ & $\begin{array}{c}0.68 \\
(0.01)\end{array}$ \\
\hline Large & $\begin{array}{c}0.79 \\
(0.01)\end{array}$ & $\begin{array}{c}0.80 \\
(0.01)\end{array}$ & $\begin{array}{c}0.43 \\
(0.01)\end{array}$ & $\begin{array}{c}0.61 \\
(0.01)\end{array}$ & $\begin{array}{c}0.20 \\
(0.12)\end{array}$ & $\begin{array}{c}0.64 \\
(0.01)\end{array}$ & $\begin{array}{c}0.24 \\
(0.08)\end{array}$ & $\begin{array}{c}0.06 \\
(0.02)\end{array}$ & $\begin{array}{c}0.06 \\
(0.64)\end{array}$ & $\begin{array}{c}0.18 \\
(0.20)\end{array}$ & $\begin{array}{c}0.67 \\
(0.01)\end{array}$ & $\begin{array}{c}0.63 \\
(0.01)\end{array}$ & $\begin{array}{c}0.26 \\
(0.03)\end{array}$ & $\begin{array}{c}0.39 \\
(0.01)\end{array}$ & $\begin{array}{c}0.28 \\
(0.12)\end{array}$ & $\begin{array}{c}0.36 \\
(0.01)\end{array}$ \\
\hline \multicolumn{17}{|c|}{ Panel B. Cash Holdings } \\
\hline Small & $\begin{array}{c}0.02 \\
(0.95)\end{array}$ & $\begin{array}{c}-0.07 \\
(0.30)\end{array}$ & $\begin{array}{c}-0.58 \\
(0.11)\end{array}$ & $\begin{array}{c}-0.19 \\
(0.26)\end{array}$ & $\begin{array}{r}-0.10 \\
(0.83)\end{array}$ & $\begin{array}{c}0.44 \\
(0.11)\end{array}$ & $\begin{array}{c}-0.37 \\
(0.41)\end{array}$ & $\begin{array}{c}-0.29 \\
(0.19)\end{array}$ & $\begin{array}{l}-0.19 \\
(0.64)\end{array}$ & $\begin{array}{l}-0.17 \\
(0.47)\end{array}$ & $\begin{array}{c}-1.22 \\
(0.03)\end{array}$ & $\begin{array}{l}-1.57 \\
(0.02)\end{array}$ & $\begin{array}{c}-0.34 \\
(0.62)\end{array}$ & $\begin{array}{l}-0.47 \\
(0.23)\end{array}$ & $\begin{array}{c}0.62 \\
(0.18)\end{array}$ & $\begin{array}{c}0.64 \\
(0.01)\end{array}$ \\
\hline 2 & $\begin{array}{c}-0.56 \\
(0.23)\end{array}$ & $\begin{array}{c}-0.56 \\
(0.05)\end{array}$ & $\begin{array}{r}-1.55 \\
(0.01)\end{array}$ & $\begin{array}{c}-1.06 \\
(0.01)\end{array}$ & $\begin{array}{c}-0.15 \\
(0.31)\end{array}$ & $\begin{array}{c}-1.04 \\
(0.05)\end{array}$ & $\begin{array}{r}-1.37 \\
(0.01)\end{array}$ & $\begin{array}{r}-1.40 \\
(0.01)\end{array}$ & $\begin{array}{l}-1.00 \\
(0.02)\end{array}$ & $\begin{array}{c}-1.15 \\
(0.01)\end{array}$ & $\begin{array}{l}-0.43 \\
(0.44)\end{array}$ & $\begin{array}{l}-0.16 \\
(0.24)\end{array}$ & $\begin{array}{c}-0.55 \\
(0.33)\end{array}$ & $\begin{array}{c}-1.95 \\
(0.01)\end{array}$ & $\begin{array}{c}-0.72 \\
(0.16)\end{array}$ & $\begin{array}{c}-0.22 \\
(0.41)\end{array}$ \\
\hline 3 & $\begin{array}{c}-2.10 \\
(0.01)\end{array}$ & $\begin{array}{c}-2.43 \\
(0.01)\end{array}$ & $\begin{array}{r}-2.96 \\
(0.01)\end{array}$ & $\begin{array}{c}-1.57 \\
(0.01)\end{array}$ & $\begin{array}{c}-2.83 \\
(0.01)\end{array}$ & $\begin{array}{c}-2.36 \\
(0.01)\end{array}$ & $\begin{array}{c}-2.48 \\
(0.01)\end{array}$ & $\begin{array}{c}-2.27 \\
(0.01)\end{array}$ & $\begin{array}{l}-1.94 \\
(0.01)\end{array}$ & $\begin{array}{c}-1.30 \\
(0.01)\end{array}$ & $\begin{array}{c}-1.68 \\
(0.01)\end{array}$ & $\begin{array}{l}-2.77 \\
(0.01)\end{array}$ & $\begin{array}{c}-3.85 \\
(0.01)\end{array}$ & $\begin{array}{c}-4.62 \\
(0.01)\end{array}$ & $\begin{array}{c}-1.42 \\
(0.01)\end{array}$ & $\begin{array}{c}-0.96 \\
(0.01)\end{array}$ \\
\hline 4 & $\begin{array}{c}-3.29 \\
(0.01)\end{array}$ & $\begin{array}{c}-2.86 \\
(0.01)\end{array}$ & $\begin{array}{c}-2.61 \\
(0.01)\end{array}$ & $\begin{array}{c}-1.51 \\
(0.01)\end{array}$ & $\begin{array}{c}-4.25 \\
(0.01)\end{array}$ & $\begin{array}{c}-3.13 \\
(0.01)\end{array}$ & $\begin{array}{c}-2.28 \\
(0.01)\end{array}$ & $\begin{array}{c}-1.11 \\
(0.01)\end{array}$ & $\begin{array}{c}-1.13 \\
(0.01)\end{array}$ & $\begin{array}{c}-0.11 \\
(0.08)\end{array}$ & $\begin{array}{c}-2.53 \\
(0.01)\end{array}$ & $\begin{array}{l}-2.79 \\
(0.01)\end{array}$ & $\begin{array}{c}-3.63 \\
(0.01)\end{array}$ & $\begin{array}{c}-3.12 \\
(0.01)\end{array}$ & $\begin{array}{l}-3.78 \\
(0.01)\end{array}$ & $\begin{array}{c}-2.34 \\
(0.01)\end{array}$ \\
\hline Large & $\begin{array}{c}-3.21 \\
(0.01)\end{array}$ & $\begin{array}{c}-2.14 \\
(0.01)\end{array}$ & $\begin{array}{c}-1.09 \\
(0.01)\end{array}$ & $\begin{array}{c}-0.88 \\
(0.01)\end{array}$ & $\begin{array}{c}-3.10 \\
(0.01)\end{array}$ & $\begin{array}{c}-1.48 \\
(0.01)\end{array}$ & $\begin{array}{c}-2.50 \\
(0.01)\end{array}$ & $\begin{array}{c}-1.76 \\
(0.01)\end{array}$ & $\begin{array}{l}-0.17 \\
(0.53)\end{array}$ & $\begin{array}{c}0.10 \\
(0.35)\end{array}$ & $\begin{array}{c}-2.54 \\
(0.01)\end{array}$ & $\begin{array}{c}-2.07 \\
(0.01)\end{array}$ & $\begin{array}{c}-2.08 \\
(0.53)\end{array}$ & $\begin{array}{c}-0.93 \\
(0.01)\end{array}$ & $\begin{array}{c}-4.43 \\
(0.01)\end{array}$ & $\begin{array}{c}-2.75 \\
(0.01)\end{array}$ \\
\hline
\end{tabular}




\section{Conclusion}

Survey evidence presented by Brav et al. (2005) and the amount of resources spent by firms on investor relations indicate that the shareholder base is of importance to firms. One reason why a large shareholder base is important is that it reduces the cost of external financing. First, having a large shareholder base may reduce asymmetric information between insiders and outsiders through more information production. Second, the shareholder base may be related to the recognition of the firm and hence the availability of external financing. For example, Merton ((1987), p. 500) states that "an increase in the relative size of the firm's investor base will reduce the firm's cost of capital and increase the market value of the firm." Common to both the asymmetric information and the recognition story is that the cost of external financing is negatively related to the size of the shareholder base.

We develop and test three implications of there being a relation between the shareholder base and the cost of external financing. First, we verify that firms with small shareholder bases behave as if they are financially constrained: They pay out less and have higher cash reserves. Second, we document that the method of payout affects the size of the shareholder base. Undertaking a repurchase reduces the size of the shareholder base, while a special dividend is neutral or even has a slight positive effect. Third, we document that firms that have small shareholder bases are less likely to undertake a repurchase (reduce the shareholder base further), thereby effectively avoiding a smaller shareholder base. However, small shareholder base firms are more likely to use special dividends as a distribution method. Overall, the findings of this paper suggest that the shareholder base not only affects firm valuation but is also an important consideration for payout policy.

The findings of this paper suggest that further research should examine how recognition interacts with firm decisions. A recent example of this is Lou (2010), who finds that firms increase advertising prior to undertaking seasoned equity offerings. However, additional work is needed to strengthen the link between recognition, returns, and corporate policies of firms.

\section{Appendix. Variable Definitions}

Shareholder base. Number of common shareholders of record (in 000s) CRSP-Compustat Merged database (CCM) data 100.

Market cap. Year-end equity market capitalization: (price $\times$ shares outstanding): CCM data $24 \times$ data 25 .

Book-to-market (BM). Ratio of long-term debt to the total equity of the firm: CCM data $9 /$ data 60.

Price-to-earnings ( $P E$ ). Ratio of the year-end stock price to earnings per share for the prior fiscal year: CCM data 24/data 58 .

Debt-to-equity $(D E)$. Ratio of long-term debt to the total equity of the firm: CCM data 9/data 60.

Operating income. Ratio of operating income to total assets: CCM data 13/data 6.

$R \& D$. Ratio of research and development to total assets, set 0 when missing: CCM data 46/data 12.

Cash. Ratio of cash holdings to total assets: CCM data 1/data 6.

Dividend payout. Ratio of dollar amount of dividends to total assets: CCM data 21/data 6. 
Total payout. Sum of dollar amount of dividends and dollar volume of repurchases divided by total assets: CCM (data 21 + data 115)/data 6 .

Stock liquidity. Sum of the monthly share volume over the previous year divided by the number of shares outstanding at the end of the year: CRSP monthly stocks.

Past year return. Compounded monthly return for the previous year: CRSP monthly stocks.

Volatility. Stock return volatility, computed as the standard deviation of daily stock returns for the previous year: CRSP daily stocks.

Capital expenditure (Capex). Ratio of capital expenditure to total assets of the firm: CCM data 128 /data 6.

Firm age. Number of years the firm existed in CRSP daily stocks database.

Share price. Median price of the firm share over the previous 1 year: CRSP daily stocks.

$R O E$. Ratio of earnings to average equity for the prior fiscal year: CCM data 20/(data $60+$ data $60(t-1)) / 2)$.

Institutional ownership (IO). Year-end fraction of shares outstanding owned by institutional fund managers: Spectrum 13f.

Industry concentration. Sum of the squared market share of each firm in the same industry during a year. Market share is defined as the total sales of the firm in a given year divided by the total sales of the industry in the year. The industry is defined at the 3-digit Standard Industrial Classification (SIC) code level, where the SIC codes have been obtained from CRSP monthly stocks (variable SICCD). The sales data come from CCM: data 12.

Misvaluation $(R R V)$. Sector-adjusted firm-specific valuation errors corresponding to the residuals of Model 3 in RRV (2005), which regresses market value on leverage, book value of assets, and net income for 12 Fama-French (1997) sectors of the economy. Estimated from CCM.

Whited-Wu index. Index of financial constraint of Whited-Wu (2006): WW $=-0.091 \times$ $\mathrm{CF}-0.062 \times$ DIVPOS $+0.021 \times \mathrm{TLTD}-0.044 \times \mathrm{LNTA}+0.102 \times \mathrm{ISG}-0.035 \times \mathrm{SG}$, where $\mathrm{CF}$ is a ratio of cash flows to total assets, DIVPOS is an indicator that takes the value of 1 if the firm pays cash dividends, TLTD is the ratio of the long-term debt to total assets, LNTA is the natural log of total assets, ISG is the firm's 3-digit industry sales growth, and SG is firm sales growth. Estimated from CCM.

Managerial ownership. Fraction of shares outstanding pertaining to the top 5 company executives. Estimated from Thomson Reuters Insider Database.

Option-based compensation $(O B C)$. The proportion of total compensation to the management officers of the firm paid in the form of stock options. Estimated from Thomson Reuter Insiders database.

Board independence. Ratio of independent directors to total directors. Estimated from IRRC.

Board size. Number of directors divided by the logarithm of total assets. Estimated from IRRC.

Corporate governance index $(G)$. Measured as in Gompers et al. (2003): Sum of the number of provisions restricting shareholder rights. Data obtained from IRRC.

Special dividend dummy. A dummy variable that takes a value of 1 if a company paid special dividends in a given year, and 0 otherwise. A dividend is classified as special if it has a distribution code of 1262 or 1272. Estimated from CRSP monthly data.

Need external financing. A dummy variable with a value of 1 if the firm's actual growth rate exceeds its sustainable growth rate. Following Demirgüç-Kunt and Maksimovic (1998) and Durnev and Kim (2005), actual growth is measured as the 2-year geometric average of the annual growth rate in total assets and sustainable growth rate as a 2-year average of ROE/(1 - ROE).

Share repurchase dummy. A dummy variable that takes a value of 1 if a company repurchased shares in a given year, and 0 otherwise. A company is defined to have a repurchase if the purchase of common and preferred stock less the decrease in par value of preferred stock (CCM data $115+$ data 130$)$ is greater than $1 \%$ of total assets. 


\section{References}

Amihud, Y.; H. Mendelson; and J. Uno. "Number of Shareholders and Stock Prices: Evidence from Japan." Journal of Finance, 54 (1999), 1169-1184.

Banyi, M.; E. A. Dyl; and K. Kahle. "Errors in Estimating Share Repurchases." Journal of Corporate Finance, 14 (2008), 460-474.

Barclay, M. J., and C. W. Smith Jr. "Corporate Payout Policy: Cash Dividends versus Open-Market Repurchases." Journal of Financial Economics, 22 (1988), 61-82.

Bessembinder, H. "Trade Execution Costs and Market Quality after Decimalization." Journal of Financial and Quantitative Analysis, 38 (2003), 747-777.

Bhushan, R., and P. O'Brien. "Analyst Following and Institutional Ownership." Journal of Accounting Research, 28 (1990), 55-76.

Bjerring, J. H.; J. Lakonishok; and T. Vermaelen. "Stock Prices and Financial Analysts' Recommendations." Journal of Finance, 38 (1983), 187-204.

Black, F. “The Dividend Puzzle." Journal of Portfolio Management, 2 (1976), 5-8.

Bodnaruk, A., and P. Östberg. "Does Investor Recognition Predict Returns?" Journal of Financial Economics, 91 (2009), 208-226.

Brav, A.; J. R. Graham; C. R. Harvey; and R. Michaely. "Payout Policy in the 21st Century." Journal of Financial Economics, 77 (2005), 483-527.

Brennan, M. J., and C. Tamarowski. "Investor Relations, Liquidity and Stock Prices." Journal of Applied Corporate Finance, 12 (2000), 26-37.

Brockman, P., and D. Y. Chung. "Managerial Timing and Corporate Liquidity: Evidence from Actual Share Repurchases." Journal of Financial Economics, 61 (2001), 417-448.

Bushee, B. J., and G. S. Miller. "Investor Relations, Firm Visibility and Investor Following.” Working Paper, University of Pennsylvania (2008).

Cleary, S. "The Relationship between Firm Investment and Financial Status." Journal of Finance, 54 (1999), 673-692.

Cook, D. O.; L. Krigman; and J. C. Leach. "On the Timing and Execution of Open Market Repurchases." Review of Financial Studies, 14 (2004), 463-498.

DeAngelo, H.; L. DeAngelo; and D. J. Skinner. "Special Dividends and the Evolution of Dividend Signaling." Journal of Financial Economics, 57 (2000), 309-354.

Demirgüç-Kunt, A., and V. Maksimovic. "Law, Finance, and Growth.” Journal of Finance, 53 (1998), 2107-2137.

Dimson, E., and P. R. Marsh. "An Analysis of Brokers' and Analysts' Unpublished Forecasts of UK Stock Returns." Journal of Finance, 39 (1984), 1257-1292.

Dittmar, A. "Why Do Firms Repurchase Stock?" Journal of Business, 73 (2000), 321-357.

Dittmar, A., and J. Mahrt-Smith. "Corporate Governance and the Value of Cash." Journal of Financial Economics, 83 (2007), 599-634.

Dittmar, A.; J. Mahrt-Smith; and H. Servaes. "International Corporate Governance and Corporate Cash Holdings." Journal of Financial and Quantitative Analysis, 38 (2003), 111-134.

Durnev, A., and E. H. Kim. "To Steal or Not to Steal: Firm Attributes, Legal Environment, and Valuation." Journal of Finance, 60 (2005), 1461-1493.

Easterbrook, F. H. "Two Agency-Cost Explanations of Dividends." American Economic Review, 74 (1984), 650-659.

Fama, E. F., and K. R. French. "Industry Costs of Equity." Journal of Financial Economics, 43 (1997), 153-193.

Fama, E. F., and J. D. MacBeth. "Risk, Return and Equilibrium: Empirical Tests." Journal of Political Economy, 81 (1973), 607-636.

Fang, L., and J. Peress. "Media Coverage and the Cross-Section of Stock Returns." Journal of Finance, 64 (2009), 2023-2052.

Fang, V. W.; T. H. Noe; and S. Tice. "Stock Market Liquidity and Firm Value." Journal of Financial Economics, 94 (2009), 150-169.

Fazzari, S. M.; R. G. Hubbard; and B. C. Petersen. "Financing Constraints and Corporate Investment." Brookings Papers on Economic Activity, 1 (1988), 141-206.

Foerster, S. R., and G. A. Karolyi. "The Effects of Market Segmentation and Investor Recognition on Asset Prices: Evidence from Foreign Stocks Listing in the United States." Journal of Finance, 54 (1999), 981-1013.

Furfine, C. "Decimalization and Market Liquidity." Economic Perspectives, 27 (2003), 2-12.

Gompers, P. A.; J. L. Ishii; and A. Metrick. "Corporate Governance and Equity Prices." Quarterly Journal of Economics, 118 (2003), 107-155.

Graham, J. R., and A. Kumar. "Do Dividend Clienteles Exist? Evidence on Dividend Preferences of Retail Investors." Journal of Finance, 61 (2006), 1305-1336. 
Greene, W. "Fixed Effects and Bias due to the Incidental Parameters Problem in the Tobit Model." Econometric Reviews, 23 (2004a), 125-147.

Greene, W. "The Behaviour of the Maximum Likelihood Estimator of Limited Dependent Variable Models in the Presence of Fixed Effects." Econometrics Journal, 7 (2004b), 98-119.

Grinstein, Y., and R. Michaely. "Institutional Holdings and Payout Policy." Journal of Finance, 60 (2005), 1389-1426.

Grullon, G., and D. Ikenberry. "What Do We Know About Stock Repurchases?" Journal of Applied Corporate Finance, 13 (2000), 31-51.

Grullon, G.; G. Kanatas; and J. Weston. "Advertising, Breadth of Ownership, and Liquidity.” Review of Financial Studies, 17 (2004), 439-461.

Harford, J.; S. A. Mansi; and W. F. Maxwell. "Corporate Governance and Firm Cash Holdings in the U.S.” Journal of Financial Economics, 87 (2008), 535-555.

Harris, L. Trading and Exchanges. Oxford: Oxford University Press (2003).

Holmström, B., and J. Tirole. "Market Liquidity and Performance Monitoring." Journal of Political Economy, 101 (1993), 678-709.

Hong, H.; J. D. Kubik; and J. C. Stein. "The Only Game in Town: Stock-Price Consequences of Local Bias." Journal of Financial Economics, 90 (2009), 20-37.

Hovakimian, A.; T. Opler; and S. Titman. "The Debt-Equity Choice.” Journal of Financial and Quantitative Analysis, 36 (2001), 1-24.

Ikenberry, D.; J. Lakonishok; and T. Vermaelen. "Market Underreaction to Open Market Repurchases." Journal of Financial Economics, 39 (1995), 181-208.

Ikenberry, D.; J. Lakonishok; and T. Vermaelen. "Stock Repurchases in Canada: Performance and Strategic Trading.” Journal of Finance, 55 (2000), 2373-2397.

Jensen, M. "The Agency Costs of Free Cash Flow: Corporate Finance and Takeovers." American Economic Review, 76 (1986), 323-329.

Kadlec, G. B., and J. J. McConnell. "The Effect of Market Segmentation and Illiquidity on Asset Prices: Evidence from Exchange Listings.” Journal of Finance, 49 (1994), 611-636.

Kahle, K. M. "When a Buyback Isn't a Buyback: Open-Market Repurchases and Employee Options." Journal of Financial Economics, 63 (2002), 235-261.

Kaplan, S. N., and L. Zingales. "Do Investment-Cash Flow Sensitivities Provide Useful Measures of Financing Constraints?” Quarterly Journal of Economics, 112 (1997), 169-215.

King, M. R., and D. Segal. "The Long-Term Effects of Cross-Listing, Investor Recognition, and Ownership Structure on Valuation.” Review of Financial Studies, 22 (2009), 2393-2421.

Lehavy, R., and R. G. Sloan. "Investor Recognition and Stock Returns.” Review of Accounting Studies, 13 (2008), 327-361.

Lou, D. "Attracting Investor Attention through Advertising." Working Paper, Yale University (2010).

Merton, R. C. "A Simple Model of Capital Market Equilibrium with Incomplete Information.” Journal of Finance, 42 (1987), 483-510.

Miller, J. M., and J. J. McConnell. "Open-Market Share Repurchase Programs and Bid-Ask Spreads on the NYSE: Implications for Corporate Payout Policy." Journal of Financial and Quantitative Analysis, 30 (1995), 365-382.

Newey, W. K., and K. D. West. "A Simple, Positive Semi-Definite, Heteroskedasticity and Autocorrelation Consistent Covariance Matrix.” Econometrica, 55 (1987), 703-708.

Neyman, J., and E. L. Scott. "Consistent Estimates Based on Partially Consistent Observations." Econometrica, 16 (1948), 1-32.

Opler, T.; L. F. Pinkowitz; R. M. Stulz; and R. Williamson. "The Determinants and Implications of Corporate Cash Holdings.” Journal of Financial Economics, 51 (1999), 3-46.

Rhodes-Kropf, M.; D. Robinson; and S. Viswanathan. "Valuation Waves and Merger Activity: The Empirical Evidence.” Journal of Financial Economics, 77 (2007), 561-603.

Rozeff, M. S. "Growth, Beta and Agency Costs as Determinants of Dividend Payout Ratios." Journal of Financial Research, 5 (1982), 249-259.

Stephens, C., and M. Weisbach. "Actual Share Reacquisitions in Open-Market Repurchase Programs." Journal of Finance, 53 (1998), 313-334.

Weisbenner, S. "Corporate Share Repurchases in the 1990s: What Role Do Stock Options Play?" Working Paper, University of Illinois, Urbana-Champaign (2004).

Whited, T. M., and G. Wu. "Financial Constraints Risk." Review of Financial Studies, 19 (2006), 531-559.

Womack, K. "Do Brokerage Analysts' Recommendations Have Investment Value?" Journal of Finance, 51 (1996), 137-157. 